\title{
Effect of Parameters Behavior of Simarouba Methyl Ester Operated Diesel Engine
}

\author{
Keerthi Kumar N. ${ }^{1}$, N. R. Banapurmath ${ }^{2}$, T. K. Chandrashekar ${ }^{3}$, Jatadhara G. S. ${ }^{4}$, \\ Manzoore Elahi M. Soudagar ${ }^{5}$ (D), Ali E. Anqi ${ }^{6}$ (D) M. A. Mujtaba ${ }^{7}$ (D), Marjan Goodarzi ${ }^{8,9,10, *(D)}$, \\ Ashraf Elfasakhany ${ }^{11}$, Md Irfanul Haque Siddiqui ${ }^{12}{ }^{(D}$ and Masood Ashraf Ali ${ }^{13}$
}

Citation: N., K.K.; Banapurmath, N.R.; Chandrashekar, T.K.; S., J.G.; Soudagar, M.E.M.; Anqi, A.E.; Mujtaba, M.A.; Goodarzi, M.; Elfasakhany, A.; Siddiqui,

M.I.H.; et al. Effect of Parameters Behavior of Simarouba Methyl Ester Operated Diesel Engine. Energies 2021, 14, 4973. https://doi.org/ 10.3390/en14164973

Academic Editor: Constantine D. Rakopoulos

Received: 26 June 2021

Accepted: 9 August 2021

Published: 13 August 2021

Publisher's Note: MDPI stays neutral with regard to jurisdictional claims in published maps and institutional affiliations.

Copyright: (c) 2021 by the authors. Licensee MDPI, Basel, Switzerland. This article is an open access article distributed under the terms and conditions of the Creative Commons Attribution (CC BY) license (https:// creativecommons.org/licenses/by/ $4.0 /)$.
1 Department of Mechanical Engineering, BMS Institute of Technology and Management, Yelahanka 560064, India; keerthikumarn@bmsit.in

2 Department of Mechanical Engineering, BVB College of Engineering and Technology, BVB College Campus, KLE Technological University, Hubli 580021, India; nr_banapurmath@kletech.ac.in

3 Department of Mechanical Engineering, RNS Institute of Technology, Channasandra 560098, India; tkchandrashekar@rnsit.ac.in

4 Department of Mechanical Engineering, Siddaganga Institute of Technology, Tumkur 572103, India; jatadhara@sit.ac.in

5 Department of Mechanical Engineering, School of Technology, Glocal University, Delhi-Yamunotri Marg, SH-57, Mirzapur Pole, Saharanpur 247121, India; me.soudagar@gmail.com

6 Department of Mechanical Engineering, College of Engineering, King Khalid University, Abha 61421, Saudi Arabia; aanqi@kku.edu.sa

7 Department of Mechanical Engineering, Faculty of Engineering, University of Malaya, Kuala Lumpur 50603, Malaysia; m.mujtaba@uet.edu.pk

8 Department of Medical Research, China Medical University Hospital, China Medical University, Taichung 40402, Taiwan

9 Department of Mathematics, Faculty of Science, King Abdulaziz University, P.O. Box 80259, Jeddah 21589, Saudi Arabia

10 Mechanical Engineering Department, Lamar University, Beaumont, TX 77706, USA

11 Mechanical Engineering Department, College of Engineering, Taif University, P.O. Box 11099, Taif 21944, Saudi Arabia; ashr12000@yahoo.com or a.taha@tu.edu.sa

12 Department of Mechanical Engineering, College of Engineering, King Saud University, Riyadh 11451, Saudi Arabia; msiddiqui2.c@ksu.edu.sa

13 Department of Mechanical Engineering, College of Engineering, Prince Sattam Bin Abdulaziz University, Al Kharj 16273, Saudi Arabia; mas.ali@psau.edu.sa

* Correspondence: mgoodarzi@lamar.edu

\begin{abstract}
Being an energy source of another origin, the compression ignition (CI) engine's typical design parameters might not suit Simarouba oil methyl ester (SuOME). Present experimental investigation targets are determining the effects of engine design parameters, including fuel injection pressure and nozzle geometry, on the engine, concerning performance and emissions such as carbon monoxide $(\mathrm{CO})$, unburnt hydrocarbon $(\mathrm{HC})$, oxides of nitrogen $\left(\mathrm{NO}_{\mathrm{x}}\right)$, and smoke opacity, with SuOME as fuel. Comparisons of brake thermal efficiency (BTE) and different emissions from the engine tailpipe were performed for different fuel injection pressures and a number of injector holes and diameter of orifices were opened in the injector to find the optimum combination to run the engine with SuOME. It was observed that the combined effect of an increase in injection pressure of 240 bar from 205 bar, and increasing number of injector holes from three to six with reduced injector hole diameters from 0.2 to $0.3 \mathrm{~mm}$, recorded higher brake thermal efficiency with reduced emission levels for the SuOME mode of operation compared to the baseline standard operation with SuOME. For 240 bar compared to 205 bar of injection pressure (IP) for SuOME, the BTE increased by 2.35\% and smoke opacity reduced by $1.45 \%$. For six-hole fuel injectors compared to three-hole injectors, the BTE increased by $3.19 \%$, HC reduced by $9.5 \%$, and CO reduced by $14.7 \%$. At 240 bar IP, with the six-hole injector having a $0.2 \mathrm{~mm}$ hole diameter compared to the $0.3 \mathrm{~mm}$ hole diameter, the BTE increased by $5 \%$, HC reduced by $5.26 \%$, CO reduced by $25.61 \%$, smoke reduced by $10 \%$, while $\mathrm{NO}_{\mathrm{x}}$ increased marginally by $0.27 \%$. Hence, the six-hole FI, $240 \mathrm{IP}, 0.2 \mathrm{~mm}$ FI diameter holes are suitable for diesel engine operation fueled by Simarouba biodiesel.
\end{abstract}


Keywords: simarouba oil methyl ester; fuel injection pressure; injector geometry; combustion and emissions

\section{Introduction}

An increase in global warming in the past few decades is mainly due to the exhaustive use of fossil fuel resources for human beings' comfort [1-5]. The application of CI engines is increasing daily in many sectors and contributes to generating electricity and transport [6-8]. This increased engine usage is becoming a significant problem worldwide regarding the shortfall of fossil fuel resources and pollutions [9]. Therefore, many researchers are focusing on a substitute fuel for diesel to run the engine [10,11]. Biodiesel, an oxygenated fuel produced from seeds, is considered a suitable substitute for diesel due to its similar chemical properties to diesel, and its renewability [12,13]. However, Jatropha, Mahua, Honge, Honne, Simarouba, Nigella sativa, and cottonseed are a few seeds with higher oil contents readily available in India [11,14-17]. Most of the studies revealed that the use of biodiesel directly into the engine is not suitable due to their higher viscosity or lower heating capabilities $[8,18,19]$.

An increase in performance can be obtained by blending biodiesel with diesel without modifying the engine parameters up to a certain percentage; as the percentage of blend increases, a reduction in the engine's performance is observed [20-23]. Significant modification in the engine is required if the engine is run by complete biodiesel due to its higher viscosity $[13,16,24]$. Hence, modification in engine parameters to the optimized values is suggested to run the engine operating with biodiesel. The driving forces for engine performance are engine performance, engine parameters such as fuel injection pressure, timing, the number of holes in the fuel injector, injector hole size, the compression ratio, and the combustion chamber profile. Using $20 \%$ of Jatropha and coconut biodiesel in diesel recorded an increased brake thermal efficiency of 2.6 and $1.3 \%$ compared to diesel operating with an injection pressure of 240 bar [25]. Using the same injection pressure of 240 bar increased thermal efficiency with reduced specific fuel consumption. Emissions such as $\mathrm{CO}, \mathrm{HC}$, smoke, and $\mathrm{NO}_{x}$ were observed in the engine using neem methyl ester as fuel [26]. By varying the IT and injection pressure, similar trends have increased $\mathrm{NO}_{\mathrm{x}}$ emissions [27]. This trend is due to the reduction in fuel droplets' size by $60 \%$ when injected at 240 bar compared to the injection pressure of 205 bar [28]. A higher BTE with a reduction in all emissions is obtained for engine operation of 275 bar at fuel injection timing of $21^{\circ}$ bTDC (before Top Dead Center) [29]. Increasing injection pressure more than the engine standards provides a higher spray velocity and may give rise to the problem of wall hitting. Hence, it is essential to control the fuel spray and penetration to reduce emissions [30]. More than 280 bar did not show improved results for gasoline fuel [31]. An investigation on injection pressures between 5 and $60 \mathrm{MPa}$ using five holes has been performed, and found improvements in atomization, and hence combustion, at an injection pressure of $20 \mathrm{MPa}$; a further increase in injection pressure resulted in an only small increase in efficiency [32]. Among many nonedible seed oils, oil produced from Simarouba seeds was also considered the best alternative for diesel.

Simarouba glauca, popularly known as Laxmitaru and Maruba in its origin of Central America, has a great potential to lower the demand for importing diesel [1,2]. Later, the Simarouba glauca plant was also found in the wasteland of Karnataka, Tamil Nadu, Gujarat, Orissa, and Maharashtra, where its leaves were used as medicines for cancer and its seeds for producing biodiesel, and its tree can be used as crafting wood. India's national oilseeds and vegetable oil development board has reported Simarouba glauca contains $0.06 \%$ of FFA (Free fatty acid) with sustainability up to half a year [33,34]. Biodiesel from Simarouba glauca oil can be obtained from the transesterification process using $\mathrm{KOH}$ as the catalyst and methanol as alcohol $[35,36]$. Using direct SuOME led to a reduction in emission levels, although a massive compromise in terms of SFC (Specific Fuel Consumption) and power 
output and life of injector lines. To overcome this, many researchers adopted the concept of modification in fuel injection and nozzle geometry $[37,38]$. Table 1 shows the influence of injection pressure and nozzle geometry.

Table 1. Influence of injection pressure and nozzle geometry on engine performance using different biodiesels.

\begin{tabular}{|c|c|c|c|c|}
\hline $\begin{array}{l}\text { Type of Biodiesel and } \\
\text { Blends Ratios }\end{array}$ & Engine Parameters & Engine Type & Output & Ref. \\
\hline $\begin{array}{c}\text { Simarouba oil, } \\
\text { B5, B10 B15, and B20 }\end{array}$ & $\begin{array}{l}220 \text { bar, } 23^{\circ} \text { bTDC with } \\
\text { three-hole injector }\end{array}$ & $\begin{array}{l}\text { Kirloskar, single-cylinder, } \\
3.5 \mathrm{~kW}, 1500 \mathrm{rpm} \text { naturally } \\
\text { aspirated engine }\end{array}$ & $\begin{array}{l}\mathrm{CO}_{2} \text { was lesser than diesel. } \\
\text { BTE was higher for all blends }\end{array}$ & [33] \\
\hline $\begin{array}{l}\text { Pumpkin seed oil } \\
\text { methyl ester, B25 }\end{array}$ & $\begin{array}{c}\text { CR } 16.5: 1 \text { to } 19.5: 1 \\
\text { IT } 19^{\circ} \mathrm{bTDC} \text { to } 25^{\circ} \mathrm{bTDC} \text { in } \\
\text { the range of } 2^{\circ} \mathrm{bTDC}, \mathrm{IP} \\
190 \text { bar to } 250 \mathrm{bar} \text { in the } \\
\text { range of } 20 \mathrm{bar}\end{array}$ & $\begin{array}{l}\text { Kirloskar/TV1, } 5.2 \text { kW, } \\
\text { 1500-6000 rpm }\end{array}$ & $\begin{array}{c}\text { High output with } \mathrm{CO}, \mathrm{HC} \text {, and } \\
\text { smoke reduction was observed } \\
\text { with high CR } 19.5: 1, \text { IP } 250 \text { bar } \\
\text { and IT } 25^{\circ} \text { bTDC. }\end{array}$ & [39] \\
\hline $\begin{array}{l}\text { Castor oil biodiesel, } \\
\text { B20 }\end{array}$ & $\begin{array}{l}\text { IP: } 200,250 \text { and } 300 \text { bar, } \\
\text { IT-21, 23, and } 25^{\circ} \mathrm{bTDC}\end{array}$ & $\begin{array}{c}\text { Kirloskar TV1, DI, CI, } \\
5.2 \mathrm{~kW} \text {, Speed } 1500 \mathrm{rpm}, \\
1 \mathrm{C}, 4 \mathrm{~S}\end{array}$ & $\begin{array}{l}\text { Observed increase in BSFC, } \\
\text { HRR, } \mathrm{CO}, \mathrm{HC} \text {, and smoke with a } \\
\text { reduction in BTE and } \mathrm{NO}_{\mathrm{x}} \\
\mathrm{BTE} \text { was higher for RB20 at }\end{array}$ & [40] \\
\hline $\begin{array}{c}\text { Roselle oil, } \\
\text { B20, B40 and B100 }\end{array}$ & $\begin{array}{c}\text { IP: } 180,200,220,240, \text { and } \\
260 \text { bars }\end{array}$ & $\begin{array}{c}\text { Legion Brothers, single } \\
\text { cylinder, } 3.7 \mathrm{~kW}, 1500 \mathrm{rpm}\end{array}$ & $\begin{array}{l}180 \text { bar, BSFE also lesser for RB } \\
20 \text { blends. EGT and smoke was } \\
\text { higher for the optimized fuel }\end{array}$ & [41] \\
\hline $\begin{array}{l}\text { Waste cooking oil } \\
\text { biodiesel, } \\
\text { B20 }\end{array}$ & $\begin{array}{l}\text { IP } 170 \text { bar to } 220 \text { bar, engine } \\
\text { speed at } 1000 \mathrm{rpm} \text { to } \\
3000 \mathrm{rpm}\end{array}$ & $\begin{array}{l}\text { Kirloskar TV1, DI, CI, } \\
5.2 \text { kW, } 1500 \mathrm{rpm}\end{array}$ & $\begin{array}{l}\text { UHC and smoke opacity } \\
\text { decreased while } \mathrm{NO}_{\mathrm{x}} \text { and } \mathrm{CO}_{2} \\
\text { increased with the increasing IP }\end{array}$ & [42] \\
\hline Honge oil methyl ester & $\begin{array}{c}\text { IP 210, 220, } \\
230 \text { and } 240 \text { bars, IT 19, } 23 \\
\text { and } 27^{\circ} \text { bTDC combustion } \\
\text { chamber slots 5.5, 6.5 and } \\
7.5 \mathrm{~mm} \text {. NG 3,4,5 holes }\end{array}$ & $\begin{array}{l}\text { TV1 (Kirlosker make), } 200 \\
\text { to } 225 \text { bar, } 5 \text { HP @1500 rpm }\end{array}$ & $\begin{array}{c}\text { The highest performance was } \\
\text { achieved at } 230 \text { bar }\end{array}$ & [43] \\
\hline $\begin{array}{l}\text { Simarouba oil methyl } \\
\text { ester and producer gas }\end{array}$ & $\begin{array}{c}\text { CC HCC and RCC, NG } \\
0.4 \mathrm{~mm} \text { hole size, IP } 230 \text { bar }\end{array}$ & $\begin{array}{c}\text { Kirloskar make, TV1 type, } \\
\text { 3.7 KW, } 1500 \text { rpm }\end{array}$ & $\begin{array}{c}4.3 \% \text { higher } \mathrm{BTE}, 18 \% \text { reduction } \\
\text { in smoke, } 11.6 \% \text { lesser } \mathrm{HC} \text {, } \\
14.28 \% \text { reduced } \mathrm{CO}, 3.9 \% \\
\text { increased } \mathrm{NO}_{\mathrm{x}} \text { level with } \\
\text { reduced ignition delay }\end{array}$ & [44] \\
\hline $\begin{array}{l}\text { Simarouba oil methyl } \\
\text { ester, } \\
\text { B100 }\end{array}$ & $\begin{array}{c}\text { CC- TRCC, LSCC, DSCC, } \\
\text { LDSCC, } \\
\text { NG- } 6 \text { holes with } 0.2 \text { and } \\
0.25 \mathrm{~mm}\end{array}$ & $\begin{array}{l}\text { Kirloskar make, TV1 type, } \\
5.2 \mathrm{KW}, 1500 \mathrm{rpm}\end{array}$ & $\begin{array}{l}6 \text { holes with } 0.2 \mathrm{~mm} \text { hole } \\
\text { diameter for LDSCC resulted in } \\
\text { increased performance than } \\
\text { other NG and CC }\end{array}$ & [45] \\
\hline
\end{tabular}

From the literature, the fuel injection pressure nozzle geometry viz.; the number of holes and diameter of holes has a higher impact on biodiesel-operated diesel engines [46]. This may be attributed to higher viscosity, reduced vaporization, lower heating, and spray characteristics of biodiesel fuels [47-49]. As the injection pressure increases, the area of spray increases for biodiesels. In addition, due to biodiesel's higher injection pressure, the injected fuel breaks more massive droplet sizes into a finely atomized form [50]. This gives improved engine performance compared to the baseline operation. Hence an injection pressure for $100 \% \mathrm{SuOME}$ is not optimized for use in a diesel engine. Emissions of $\mathrm{CO}_{2}$ are based on load and engine operating conditions. Hence, the $\mathrm{CO}_{2}$ emissions of biodieseloperated engine are higher than diesel modes of operation due to their low gross calorific value. On the other hand, based on the study carried by Argonne National Laboratory, use of biodiesel causes less environmental concern as the study on B100 revealed that the life cycle of greenhouse gas emission of biodiesel is $74 \%$ lesser than conventional diesel.

Similarly, as the number of injector holes increases, they tend to supply more fuel into the combustion chamber, improving combustion. However, due to the increased quantity of fuel, SFC reduces. Hence previous work showed there is a significant effect of injector hole size for different biodiesel. However, less work has been observed on a combination 
of injection pressure and the effect of injector hole diameters on engine performance using SuOME as fuel. Hence, studying the combined effects of injection pressure and injector hole size is crucial to obtain higher efficiency and reduced emissions. Hence, the current study aims to improve the overall performance of SuOME fueled diesel engines by optimizing both fuel injection pressure and injector geometry.

\section{Materials and Methods}

In the following section, details about Simarouba biodiesel's preparation, properties of prepared biodiesel, experimental setup, specifications of the setup used for experimentation, different fuel injectors used, and modifications on the engine are explained.

\subsection{Simarouba Oil Methyl Ester Production}

The details about the experimental procedure used to prepare SuOME, its characterization, and the experimental test rig used for engine experimentation are shown in the following sections. The Simarouba oil methyl ester used in the study was produced at the University of Agricultural Sciences, Bangalore. SuOME was produced from Simarouba seed oil by the transesterification process. The various steps involved in converting Simarouba seeds to their biodiesel are shown in Figure 1. The transesterification setup consists of a 3-neck round-bottom flask of $2 \mathrm{~L}$ capacity and a high-speed magnetic stirrer for mixing all the oil. $\mathrm{KOH}$ as a catalyst, and methanol as alcohol is used in the production of SuOME.

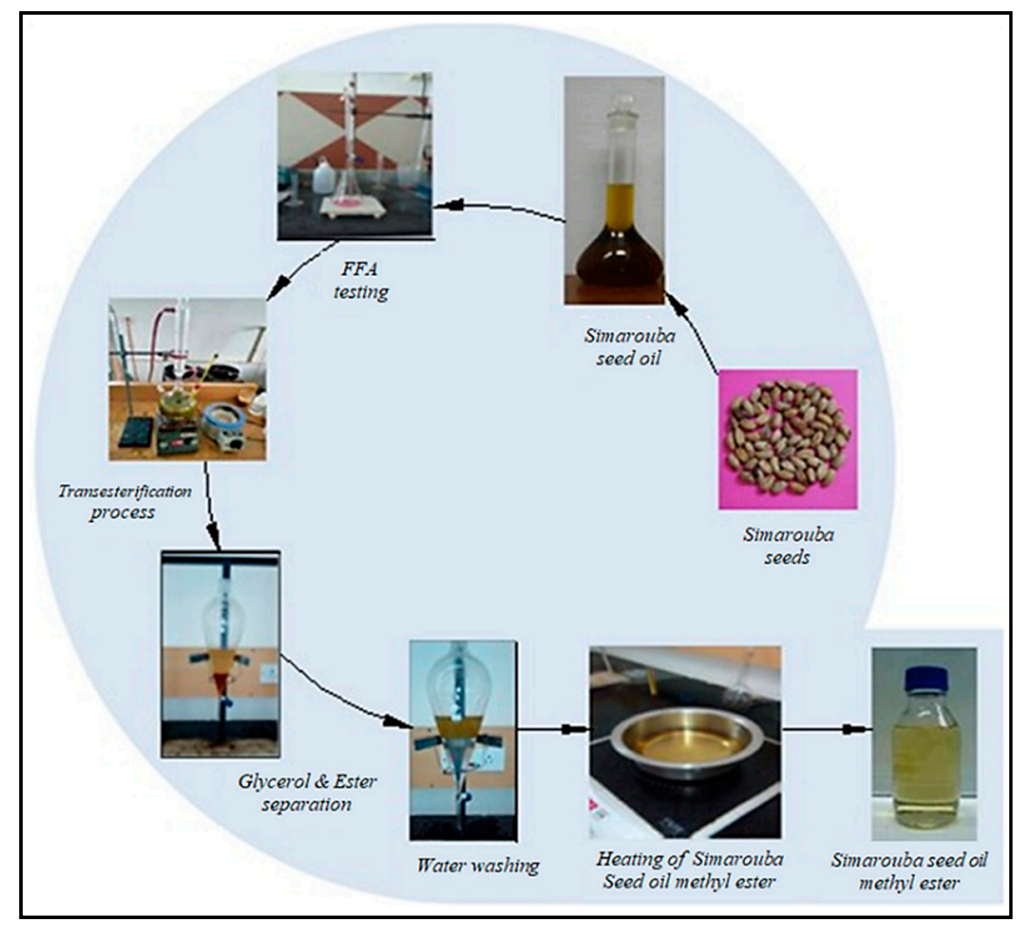

Figure 1. Steps involved in the transesterification process.

The reaction procedure involves $1000 \mathrm{gm}$ of Simarouba oil, $230 \mathrm{gm}$ of methanol, and $8 \mathrm{gm}$ of potassium hydroxide pellets mixed vigorously by starrier by maintaining a temperature of $60^{\circ} \mathrm{C}\left( \pm 2{ }^{\circ} \mathrm{C}\right)$ for $60 \mathrm{~min}$ to produce SuOME. The mixture was then transferred to a conical funnel and allowed overnight to separate the ester and glycerol by gravity. Next, glycerol, salt, and methanol were removed from the conical flask, and the esters were mixed with $250 \mathrm{gm}$ of hot water and allowed to settle for $2 \mathrm{~h}$. This assisted in separating the residual FFA and catalyst [51-54]. To remove the moisture content from the SuOME, silica gel crystals were added, and the ester was heated at $110^{\circ} \mathrm{C}$ for $2 \mathrm{~h}$. 
The properties of SuOME and the percentage of different fatty acids have been determined at the Bangalore test house, Bangalore, and shown in Tables 2 and 3, respectively. All experiments were carried with $100 \%$ pure SuOME, and the results were compared with diesel results.

Table 2. Properties of fuel samples used in the present study [45].

\begin{tabular}{ccccc}
\hline Parameters & Diesel & $\begin{array}{c}\text { Simarouba } \\
\text { Glauca }\end{array}$ & SuOME & $\begin{array}{c}\text { Test } \\
\text { Methods }\end{array}$ \\
\hline Gross calorific value, Cal/g & 10,270 & 9173 & 9399 & IS:1448 (P6) \\
Flash point, ${ }^{\circ} \mathrm{C}$ (open cup) & 55 & $>250$ & 184 & IS:1448 (P66) \\
Kinematic viscosity at $40^{\circ} \mathrm{C}, \mathrm{cSt}$ & $2.5-5$ & 41.80 & 4.9 & IS:1448 (P25) \\
Density, $\mathrm{g} / \mathrm{mL}$ at $15^{\circ} \mathrm{C}$ & 0.834 & 0.939 & 0.813 & IS:1448 (P32) \\
Iodine value, $\mathrm{mg} / \mathrm{g}$ & - & 17.7 & 17 & IS:548 \\
Cloud point, ${ }^{\circ} \mathrm{C}$ & -17 & 23 & 22 & IS:1448 (P10) \\
Acid value, $\mathrm{mg}$ of $\mathrm{KOH} / \mathrm{g}$ & - & 5.1 & 1.76 & IS:1448 (P2) \\
Color & Brown & Pale yellow & Yellow & \\
\hline
\end{tabular}

Table 3. Percentage of various fatty acids.

\begin{tabular}{cccccc}
\hline Fatty Acids & Oleic Acid & $\begin{array}{c}\text { Linoleic } \\
\text { Acid }\end{array}$ & $\begin{array}{c}\text { Linolenic } \\
\text { Acid }\end{array}$ & $\begin{array}{c}\text { Palmitic } \\
\text { Acid }\end{array}$ & Stearic Acid \\
\hline Value $(\%)$ & 59.10 & 3.30 & 0.35 & 10.90 & 25.60 \\
\hline
\end{tabular}

\subsection{Experimental Procedure}

The experimental test rig and the injector patterns used in the present study are depicted in Figure 2a,b, respectively. All the experiments were carried out on 4-stroke single-cylinder Kirloskar to make a direct injection water-cooled CI engine capacity of $5.2 \mathrm{~kW}$ at $1500 \mathrm{rpm}$. The manufacturer specified that the injection pressure is $205 \mathrm{bar}$ with a 3-hole injector with a $0.3 \mathrm{~mm}$ diameter for diesel fuel. All the experiments were carried at $1500 \mathrm{rpm}$, which the governor provided with the engine achieved. On the head of the cylinder, a piezoelectric pressure transducer was attached by the manufacturer. Emissions from the engine were measured using a DELTA 1600S (5-gas analyzer) and HARTRIDGE Smoke meter-4 to measure smoke opacity. The technical specification of the engine, 5-gas analyzer, and smoke meters are shown in Table 4.

Table 4. Specification of the engine and emission meters Reproduced from [55], Elsevier: 2020.

\begin{tabular}{ccc}
\hline No. & Particulars & Specifications \\
\hline 1 & Engine manufacturer & Kirloskar oil engines Ltd., India \\
2 & model & TV1 \\
3 & Engine & Single cylinder, 4 strokes, Direct Injection (DI) \\
4 & Bore/stroke & $87.5 \mathrm{~mm} / 110 \mathrm{~mm}$ \\
5 & Compression ratio & $17.5: 1$ \\
6 & Engine speed & $1500 \mathrm{rpm}$ \\
7 & Rated power & $5.2 \mathrm{~kW}(7 \mathrm{HP})$ \\
8 & Injection pressure & 205 bar $/ 23^{\circ}$ before TDC \\
9 & Type of sensor & Piezoelectric \\
10 & Type of gas analyzer & DELTA $1600 \mathrm{~S}$ \\
11 & Gas & HC, CO, CO, $\mathrm{O}_{2}$ and NOX \\
12 & Type of smoke meter & HARTRIDGE SMOKEMETER-4 \\
13 & Measuring range opacity & $0-100 \%$ \\
\hline
\end{tabular}




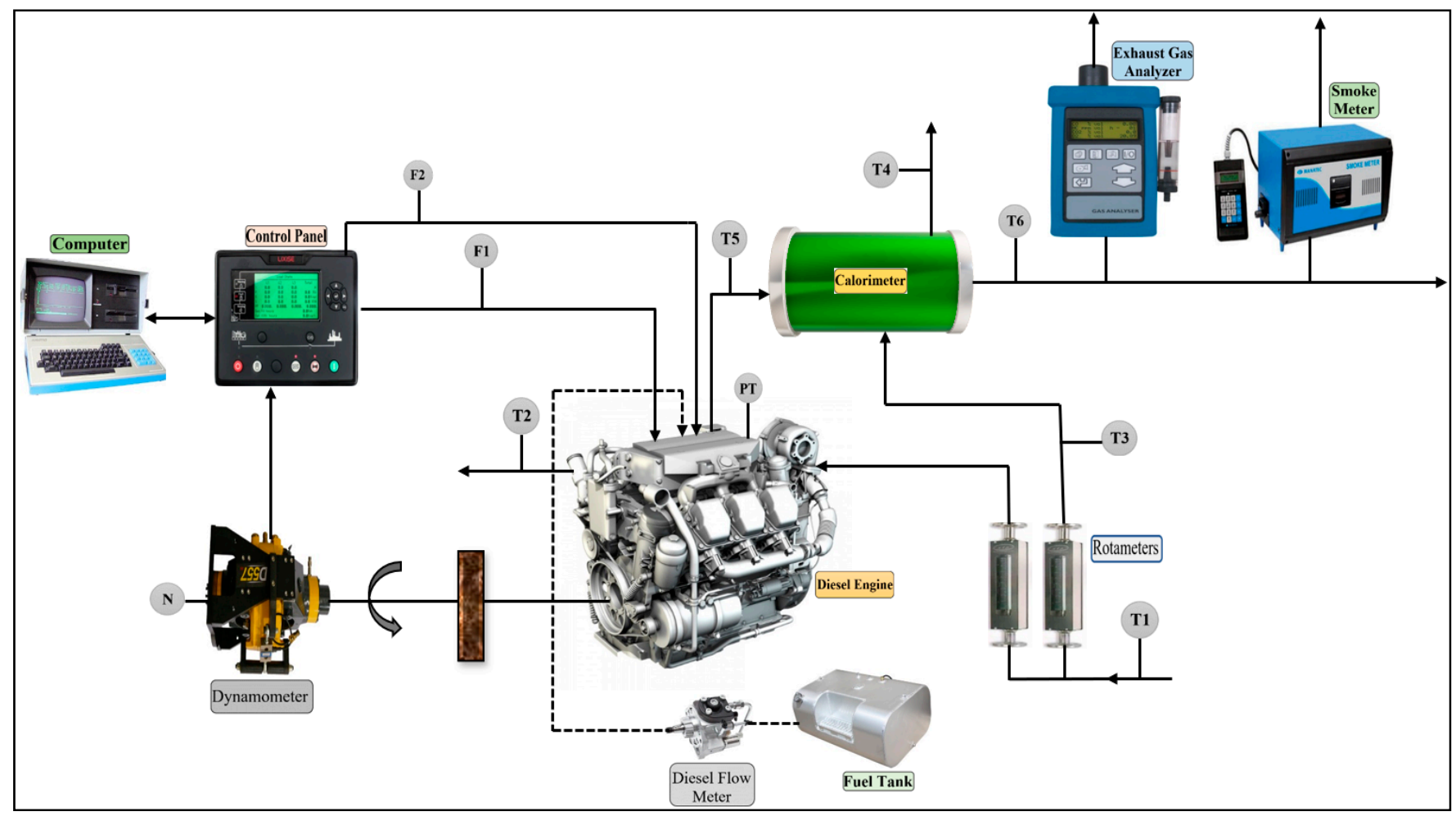

\begin{tabular}{|c|c|c|c|}
\hline T1 and T3 & Water inlet temperature & T6- & EGT after calorimeter \\
\hline $\mathbf{T} 2$ & $\begin{array}{l}\text { Engine water jacket outlet } \\
\text { temperature }\end{array}$ & F1 & $\begin{array}{l}\text { Fuel flow differential pressure (DP) } \\
\text { unit }\end{array}$ \\
\hline T4 & Calorimeter outlet temperature & F2 & Air intake DP unit \\
\hline T5 & $\begin{array}{l}\text { Exhaust gas temperature (EGT) } \\
\text { before calorimeter }\end{array}$ & PT & Pressure Transducer \\
\hline
\end{tabular}

(a) Line diagram of experimental setup (reproduced with permission from the publisher)

Figure 2. Cont. 


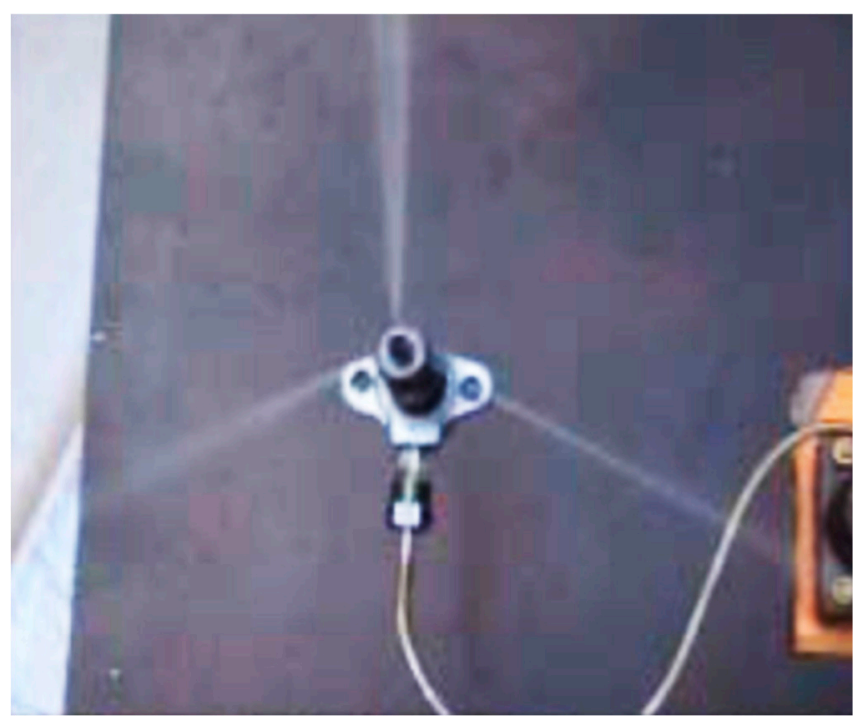

(1) 3-hole

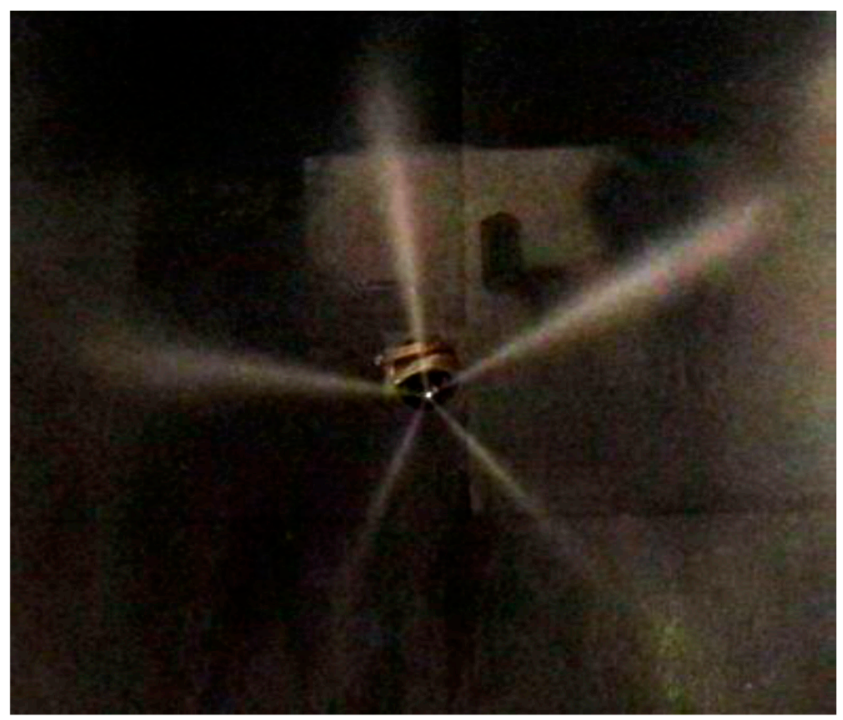

(3) 5-hole

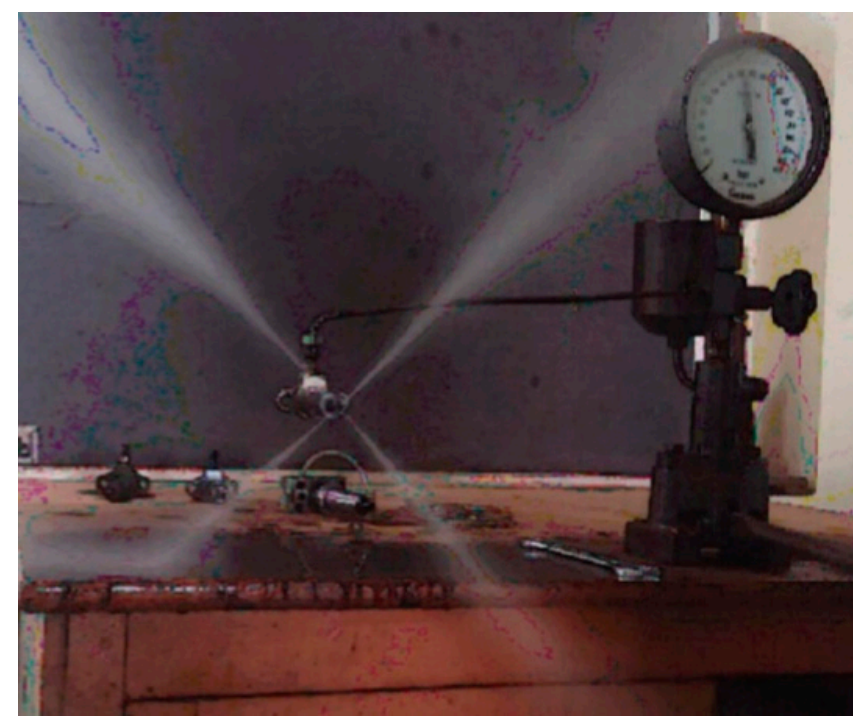

(2) 4-hole

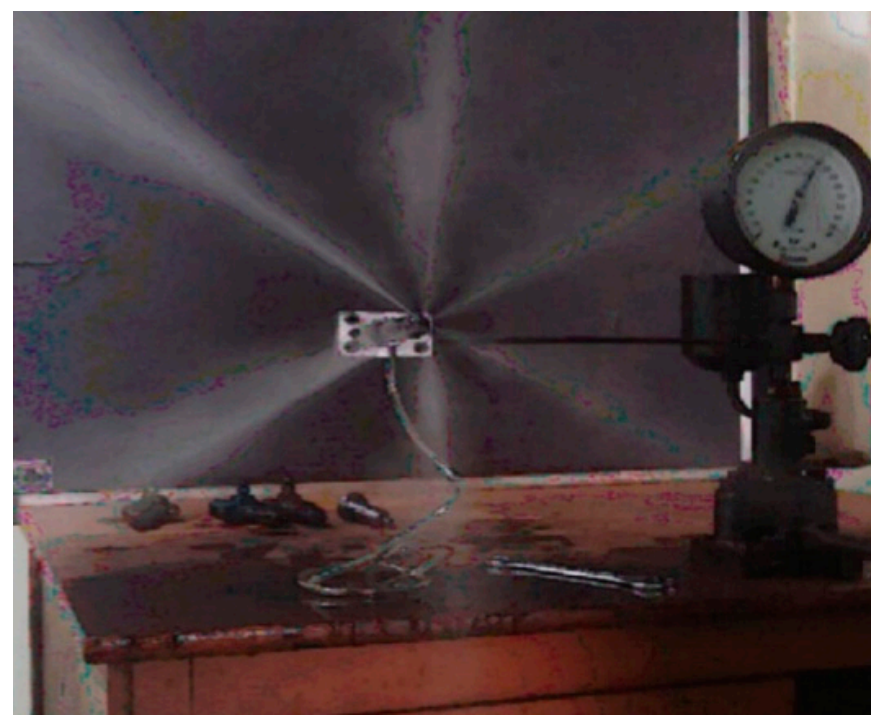

(4) 6-hole

(b) Fuel injection spray pattern

Figure 2. Engine (a) Experimental setup Reproduced from [6] Elsevier: 2019 and (b) fuel injection spray pattern Reproduced from [56] Elsevier: 2019.

\section{Results}

This section presents the outcomes of tests carried out at two different loads (4.16 and $5.2 \mathrm{~kW})$ operating at $1500 \mathrm{rpm}$ for four injection pressures $(205,220,240$, and $260 \mathrm{bar})$ and nozzle geometry (a three, four, five, and six-hole injector with 0.2, 0.25 and $0.3 \mathrm{~mm}$ ) on the performance of an engine fueled with SuOME. All the readings recorded from the instruments with the total uncertainty of $\pm 2.3 \%$ were calculated based on the square root method.

\subsection{Effect of Fuel Injector Pressure}

Baseline fuel injection pressure was 205 bar for diesel as prescribed by the engine supplier. However, to study the impact of injection pressure on SuOME mode of operation on engine performance, the injection pressure was varied from 205 to 260 bars. An optimum fuel injection pressure was fixed for SuOME for further studies based on the performance, 
emission, and combustion parameters. The optimum result was also compared with diesel with a standard manufacturer mode of injection pressure of 205 bar.

\subsubsection{Brake Thermal Efficiency}

The variation in brake thermal efficiency on a partial and full load for SuOME for different fuel injection pressures is shown in Figure 3. Higher brake thermal efficiency is observed from the engine during an $80 \%$ load of full load compared to full load for all the injection pressures and diesel. Based on the results, the highest brake thermal efficiency for SuOME mode of operation is $27.25 \%$ at 240 bar. A further increase in injection pressure resulted in a drop in brake thermal efficiency, and this may be attributed to the fact that as the injection pressure increased, the droplet size reduced and hence suffered in penetrating deeper into the combustion chamber $[57,58]$. However, due to the higher viscosity of SuOME than diesel, reduced BTE was recorded for SuOME.

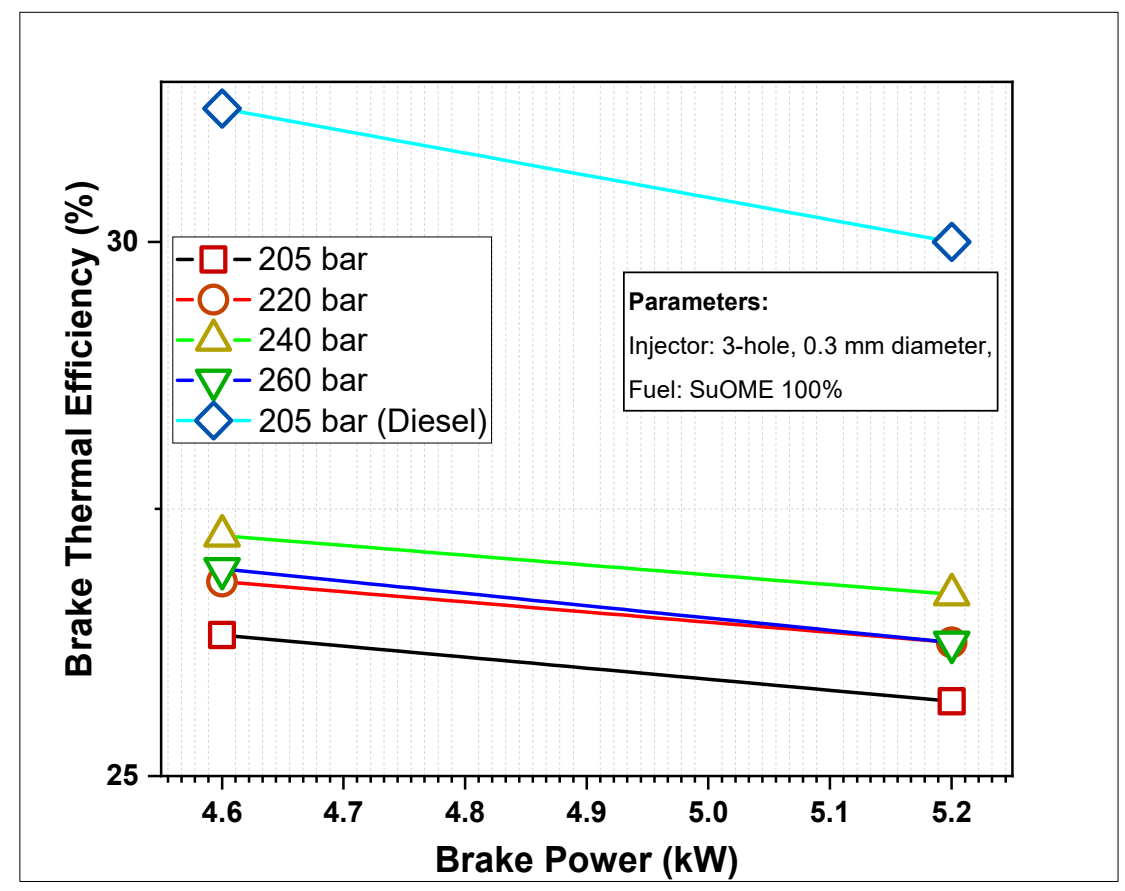

Figure 3. Variations of brake thermal efficiency over brake power.

\subsubsection{Effect on Emissions: HC, CO, Smoke, and NOx on Fuel Injector Pressure}

The emission of unburnt HC on different power for SuOME is shown in Figure 4a. A noticeable drop has been observed at 240 bar injection using a standard injector because of enhanced atomization of SuOME and better combustion for injected fuel. Ignition delay viz., the physical delay also reduced due to an increase in injection pressure. HC was reduced by 47 to $41 \mathrm{ppm}$ by increasing the injection pressure from 205 to 240 bar at a $4.16 \mathrm{~kW}$ load. Increasing the injection pressure further, the $\mathrm{HC}$ level raised to $42 \mathrm{ppm}$. This may be due to a top portion of the injected fuel burning in the combustion diffusion phase based on a smaller fuel spray and reduced ignition delay. Hence, it can be concluded that HC emissions are less at 240 bar operation with a three-hole injector, and this is due to superb atomization and increased combustion of SuOME rather than other injection pressure. 


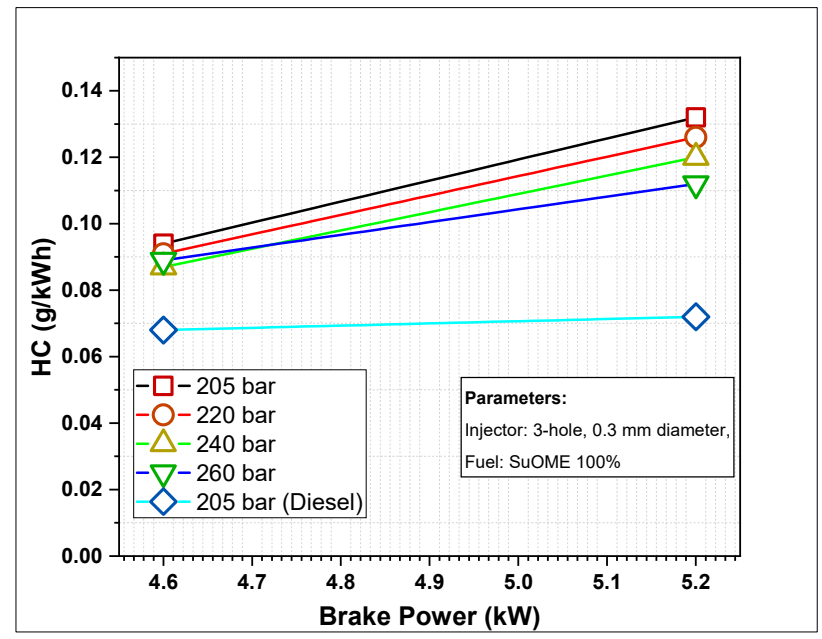

(a) Variation of HC emission over brake power

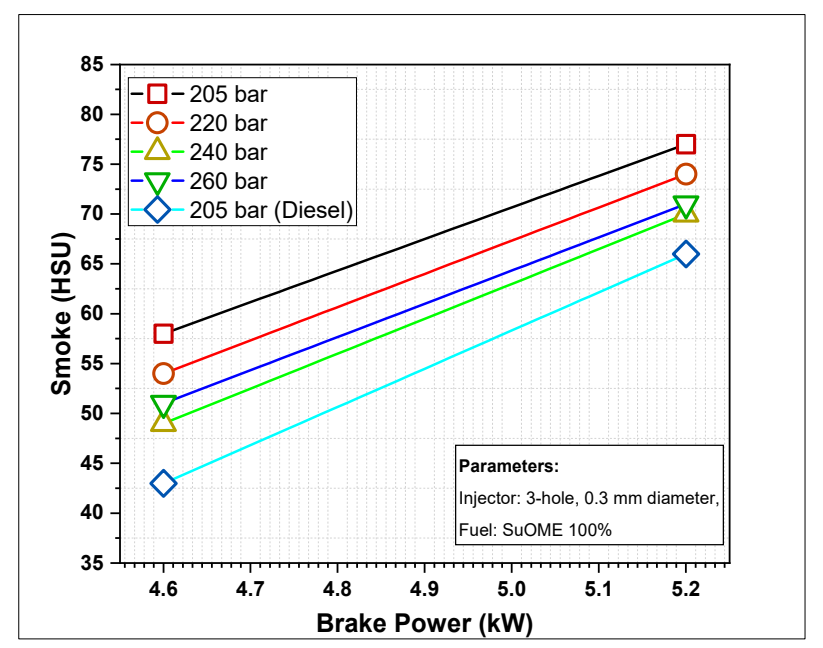

(c) Variation of smoke opacity over brake power

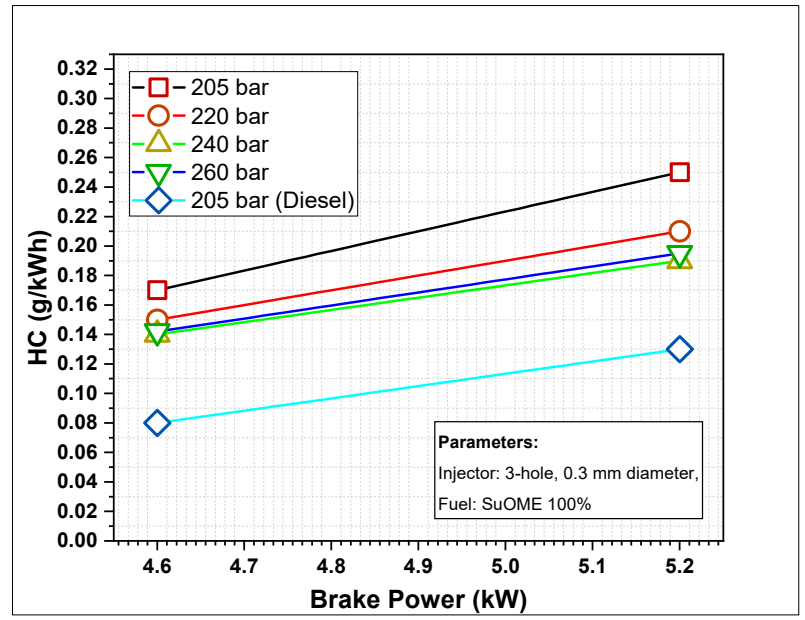

(b) Variation of $\mathrm{CO}$ emission over brake power

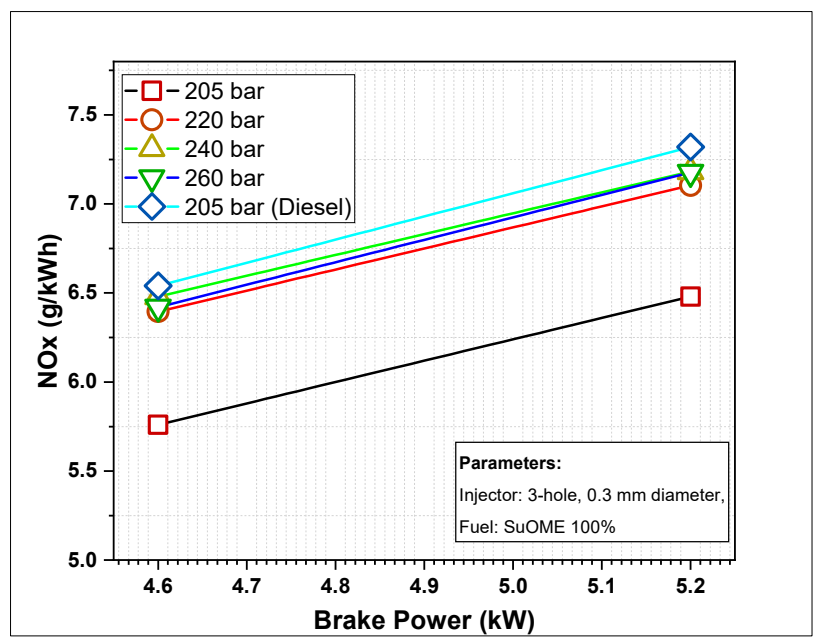

(d) Variation of $\mathrm{NO}_{\mathrm{x}}$ emission over brake power

Figure 4. Variations of (a) $\mathrm{HC}$, (b) $\mathrm{CO}$, (c) smoke and (d) $\mathrm{NO}_{x}$ at different brake power.

\subsubsection{Carbon Monoxide}

Figure $4 \mathrm{~b}$ shows $\mathrm{CO}$ emissions for a partial and full load for SuOME and diesel. CO emissions were also raised as the load increased, which could be incomplete combustion at full load. Both $\mathrm{CO}$ and $\mathrm{HC}$ emissions followed similar trends with reduced $\mathrm{CO}$ emissions at 240 bar of fuel injection than 205 bar for SuOME. CO emission at 240 bar injection pressure was $0.14 \%$ at $4.16 \mathrm{~kW}$. However, $\mathrm{CO}$ emissions for diesel were further lesser than SuOME at 240 bar injection pressure. This may be due to the complete combustion of diesel because it has a more volatile nature than SuOME [27].

\subsubsection{Smoke Opacity}

Figure 4c shows how injection pressure on smoke opacity with BP operated, using diesel and SuOME. Smoke levels were observed to fall with increased IOP compared to the standard injector opening pressure for SuOME. This trend may be attributed to improved air-fuel mixture resulting from higher atomization of SuOME. The lowest smoke level of 49 HSU has been observed at an IOP of 240 bar at $80 \%$ load. With a further increase in the IOP to 260 bar, the fuel tended to suffer in finding the fresh air for combustion [16]. Smoke opacity for IP of 205, 220, 240, and 260 bar were 58, 54, 49, and 51 HSU, respectively, for 
$80 \%$ load operated using SuOME. However, the smoke opacity for diesel was 43 HSU and was lesser than SuOME due to the fuel's complete reaction.

\subsubsection{Nitrogen Oxide}

The emission of $\mathrm{NO}_{x}$ for 80 and $100 \%$ load for SuOME fuel and diesel is shown in Figure $4 \mathrm{~d}$. The figure shows that $\mathrm{NO}_{\mathrm{x}}$ emission was uppermost at 220 bar injection pressure; the possible reason is the optimum oxygen content supply. The $\mathrm{NO}_{\mathrm{x}}$ emission decreased with an increase in injection pressure. The highest and lowest $\mathrm{NO}_{\mathrm{x}}$ emission ranged from 1080 and $960 \mathrm{ppm}$, respectively. At $4.16 \mathrm{~kW}$, the $\mathrm{NO}_{\mathrm{x}}$ emission was 0.094, 0.091, 0.087, 0.089 , and $0.068 \mathrm{~g} / \mathrm{kWh}$, and the corresponding injection pressure 205, 220, 240, $260 \mathrm{bar}$ for SuOME and 205 bar for diesel.

\subsection{Influence of Number of Injector Holes and Their Orifice Diameter}

This section shows the effect of different numbers of injector holes and their orifice diameter on the performance of SuOME fueled engines. To study the effect of the number of injector holes, a three, four, five, and six-hole injector was used, and based on the results, a six-hole injector was optimized. A six-hole injector was used with a varied orifice diameter of $0.3,0.25$, and $0.2 \mathrm{~mm}$ to study the effect of the nozzle orifice diameter.

\subsubsection{Brake Thermal Efficiency}

The variation of BTE for SuOME injected with three, four, five and six-hole injectors of orifice diameter $0.3 \mathrm{~mm}$ is shown in Figure 5a. Figure $5 \mathrm{~b}$ shows the variation of BTE of six-hole injectors having an orifice diameter of $0.3,0.25$, and $0.2 \mathrm{~mm}$. As the number of holes increases, the amount of high viscous fuel injected will increase. Hence a 3.2\% increase in BTE with a six-hole injector has been recorded compared to the three-hole injector, which operated at 240 bar of injection pressure with SuOME. On the other side, as the orifice size reduced from 0.3 to $0.2 \mathrm{~mm}$, enhanced fuel-air mixture formation occurred inside the CC, which tends to increase the combustion rate and hence, there was a higher BTE $[20,59]$. However, increasing the number of orifice holes to more than six is practically impossible, and reducing the orifice diameter to less than $0.2 \mathrm{~mm}$ nullified the above effect as the injected fuel moves much faster than air. This tends to reduce mixture formation and results in a reduction in engine performance $[58,60,61]$.

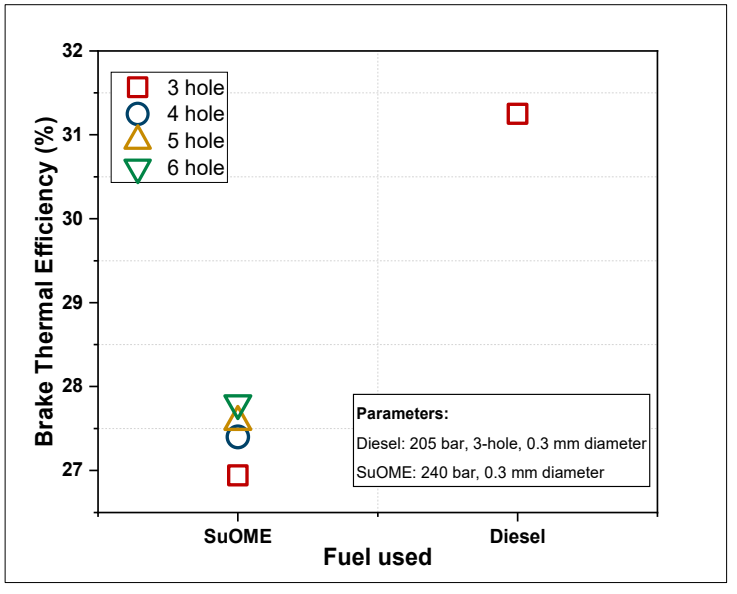

(a) Variation of BTE over the number of injector holes

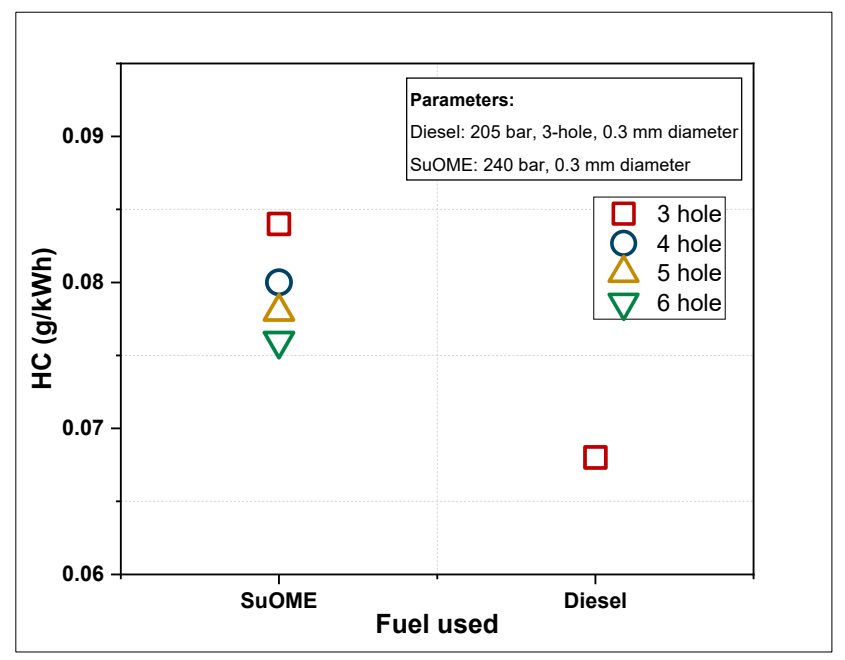

(b) Variation of BTE oversize of injector holes

Figure 5. Variations of BTE upon (a) number of injector holes and (b) orifice diameter of the injector. 


\subsubsection{Unburnt Hydrocarbon and Carbon Monoxide Emissions}

Variation of HC and CO emissions for SuOME fuel injected with three, four, five, and six holes with an orifice diameter of $0.3 \mathrm{~mm}$ and the effect of injector orifice diameter for six-hole injectors is shown in Figure $6 \mathrm{a}, \mathrm{b}$ and Figure $6 \mathrm{c}, \mathrm{d}$, respectively. HC and CO emissions from six-hole injectors for SuOME are $38 \mathrm{ppm}$ and $0.121 \%$, whereas $\mathrm{HC}$ and $\mathrm{CO}$ emissions from three-hole injectors for SuOME fuel are $42 \mathrm{ppm}$ and $0.142 \%$. Based on the emissions of $\mathrm{HC}$ and $\mathrm{CO}$, a six-hole injector was used for further studying the effect of the orifice hole diameter. $\mathrm{HC}$ and $\mathrm{CO}$ emissions from the $0.3,0.25$, and $0.2 \mathrm{~mm}$ orifice diameters were 38,37 , and $36 \mathrm{ppm}$ and $0.121,0.111$, and $0.09 \%$, respectively. For the same power to develop, more SuOME needed to be injected, and hence higher $\mathrm{HC}$ and $\mathrm{CO}$ were observed than diesel. However, larger hole diameters tended to deposit injected fuel onto the walls of the combustion chambers $[27,46]$. Hence $\mathrm{HC}$ and $\mathrm{CO}$ were greater with a standard injector.

\subsubsection{Smoke Opacity}

The influence of the number of injector holes on smoke opacity is shown in Figure 6e. As the number of holes increases in the injector nozzle, the smoke opacity of SuOME operated engine reduces. Smoke opacity for SuOME mode of operation using three, four, five, and six-hole injectors with $0.3 \mathrm{~mm}$ diameter was $51,51,50$, and 49.5 , respectively. This may be attributed to the fact that holes directly affect increased the fuel-air mixture formation and reduced smoke $[62,63]$. Higher smoke emission was observed with three, four, and five-hole nozzles due to the improper fuel-air mixture. Another reason for the reduced smoke emissions may be due to the higher BTE [36].

The influence of injector orifice diameter on smoke opacity for SuOME fueled CI engine is presented in Figure 6f. Compared to the six-hole with an $0.3 \mathrm{~mm}$ orifice diameter, smoke opacity from an $0.2 \mathrm{~mm}$ diameter showed reduced smoke opacity. By reducing the injector orifice diameter from 0.3 to $0.2 \mathrm{~mm}$ diameter, smoke emission was reduced by $10 \%$. This may be attributed to the fact that as the orifice's diameter reduced the atomization of fuel, a more delicate spray of highly viscous SuOME resulted in nearly complete combustion of supplied fuel, with higher BTE and reduced smoke opacity [2].

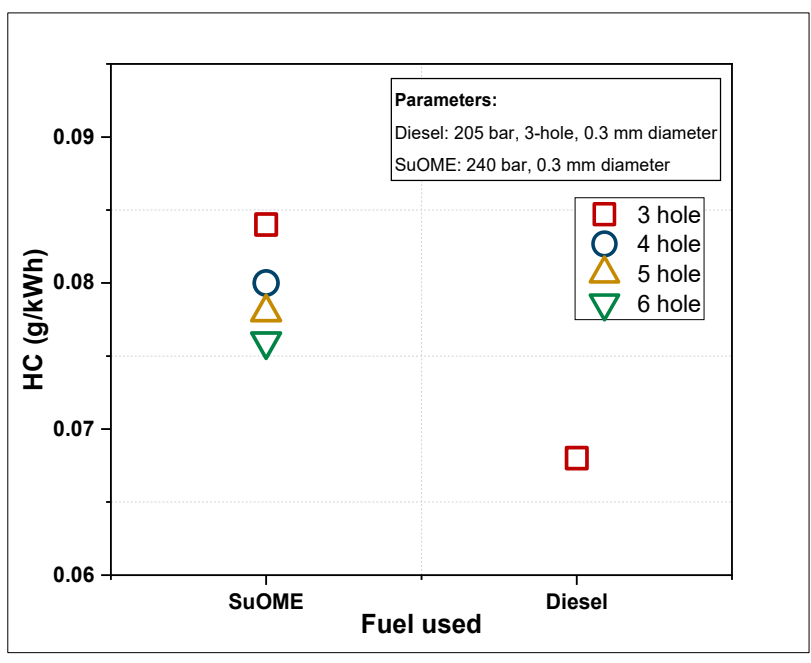

(a) Variation of HC emission over number of injector holes

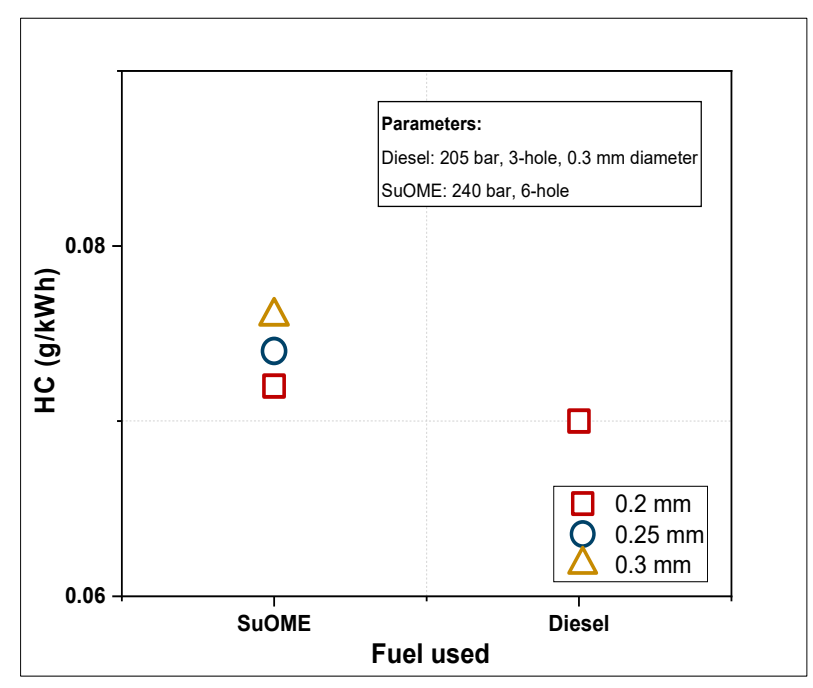

(b) Variation of HC emission over size of injector holes

Figure 6. Cont. 


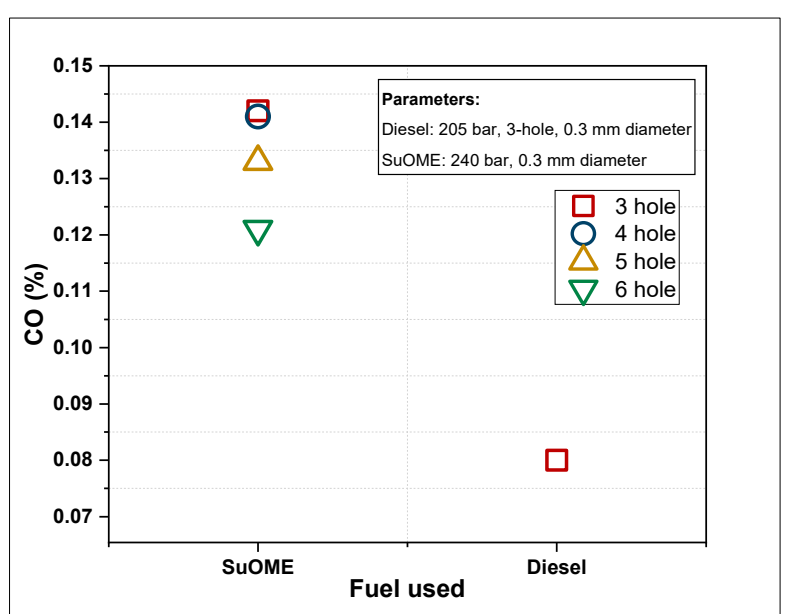

(c) Variation of $\mathrm{CO}$ emission over number of injector holes

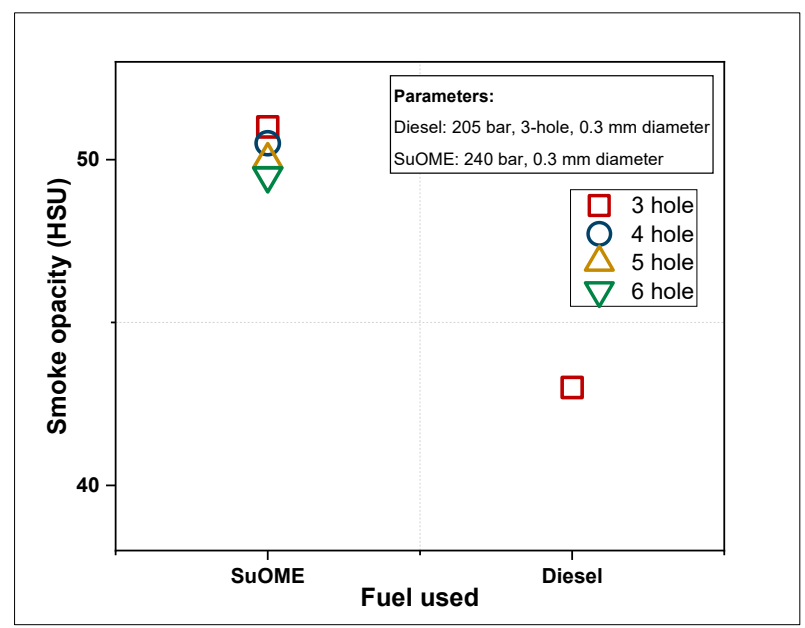

(e) Variation of smoke opacity over number of injector holes

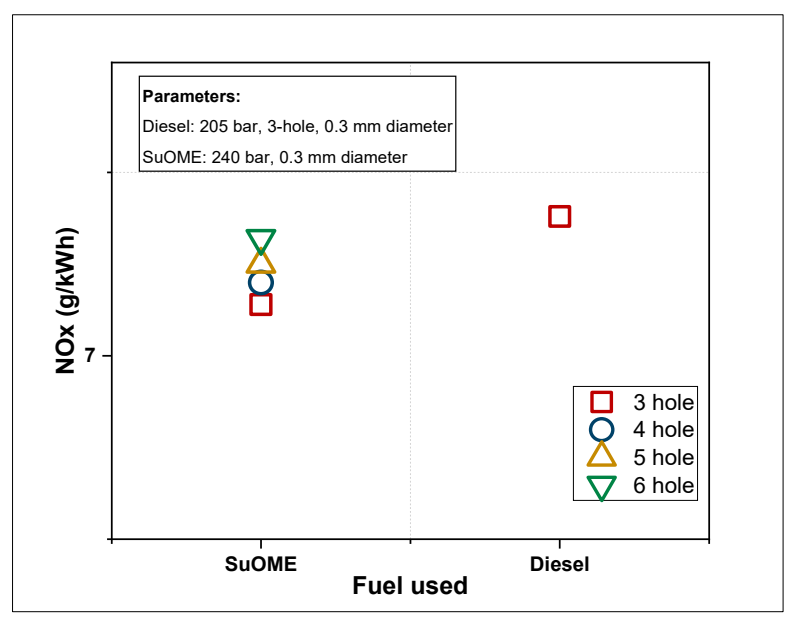

(g) Variation of $\mathrm{NO}_{x}$ emission over the number of injector holes

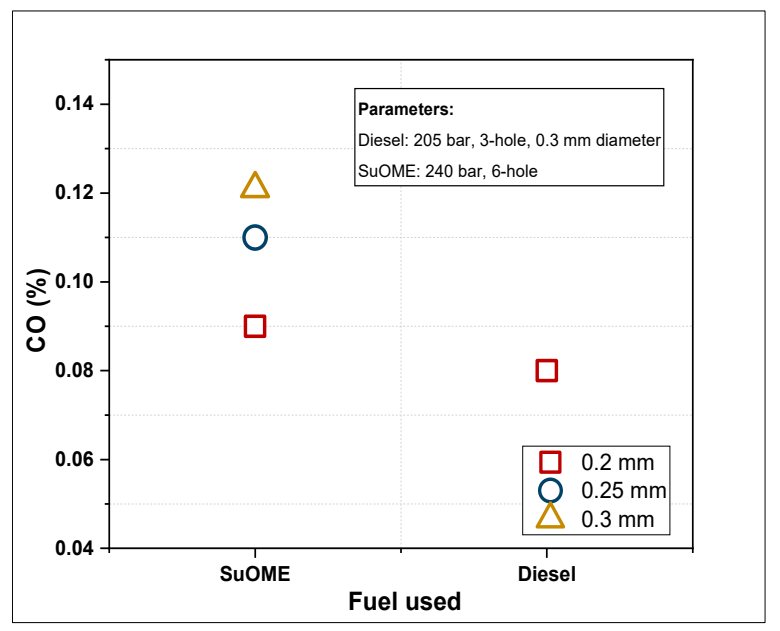

(d) Variation of CO emission over size of injector holes

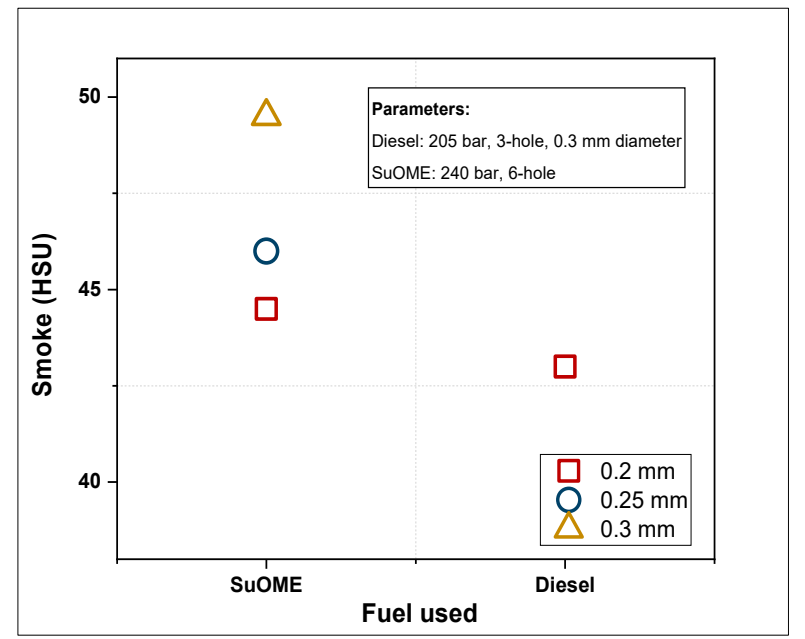

(f) Variation of smoke opacity over size of injector holes

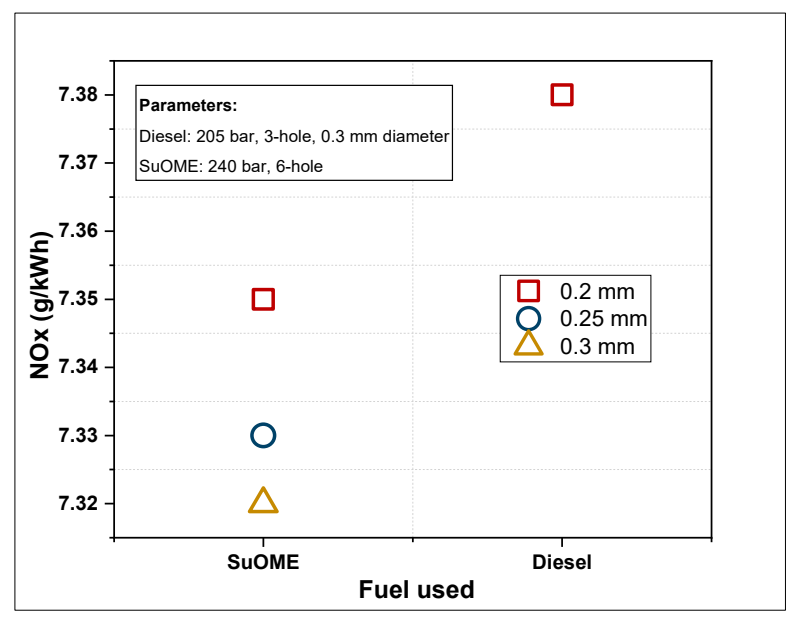

(h) Variation of $\mathrm{NO}_{x}$ emission over the size of injector holes

Figure 6. Variations of emissions on number of injector holes and orifice diameter of the injector: (a) and (b) HC; (c) and (d) $\mathrm{CO} ;(\mathbf{e})$ and (f) smoke; (g) and (h) $\mathrm{NO}_{\mathrm{x}}$. 


\subsubsection{Nitrogen Oxide}

Variations of emissions of oxides of nitrogen with three, four, five, and six-hole injector and six-hole injectors with an orifice diameter of $0.3,0.25$, and $0.2 \mathrm{~mm}$ for a SuOME operated engine are shown in Figure $6 \mathrm{~g}, \mathrm{~h}$, respectively. $\mathrm{NO}_{\mathrm{x}}$ emissions depended on combustion temperature in the adiabatic flam region. Higher $\mathrm{NO}_{\mathrm{x}}$ was observed with the diesel mode of operation due to the higher combustion temperature of low volatile diesel than SuOME [27]. $\mathrm{NO}_{x}$ emission was higher for a six-hole injector with an orifice diameter of $0.2 \mathrm{~mm}$ than a three-hole injector with a $0.3 \mathrm{~mm}$ orifice diameter by $12 \mathrm{ppm}$. This increase in $\mathrm{NO}_{\mathrm{x}}$ for small hole injectors was due to superior combustion and increased heat release rate inside the combustion chamber at premixed combustion [64].

\subsection{Combustion Analysis}

Figure 7a shows the in-cylinder pressure for diesel and SuOME for six-hole injectors with a $0.3,0.25$, and $0.2 \mathrm{~mm}$ orifice diameter. The data for cylinder pressures for different crank angles are obtained from an average of 500 cycles for SuOME, diesel fuel only for $80 \%$ loading of full load. SuOME with an injector orifice diameter of $0.2 \mathrm{~mm}$ showed peak pressure near to the diesel mode of operation. Peak pressure with other injectors recorded reduced in-cylinder peak pressure.

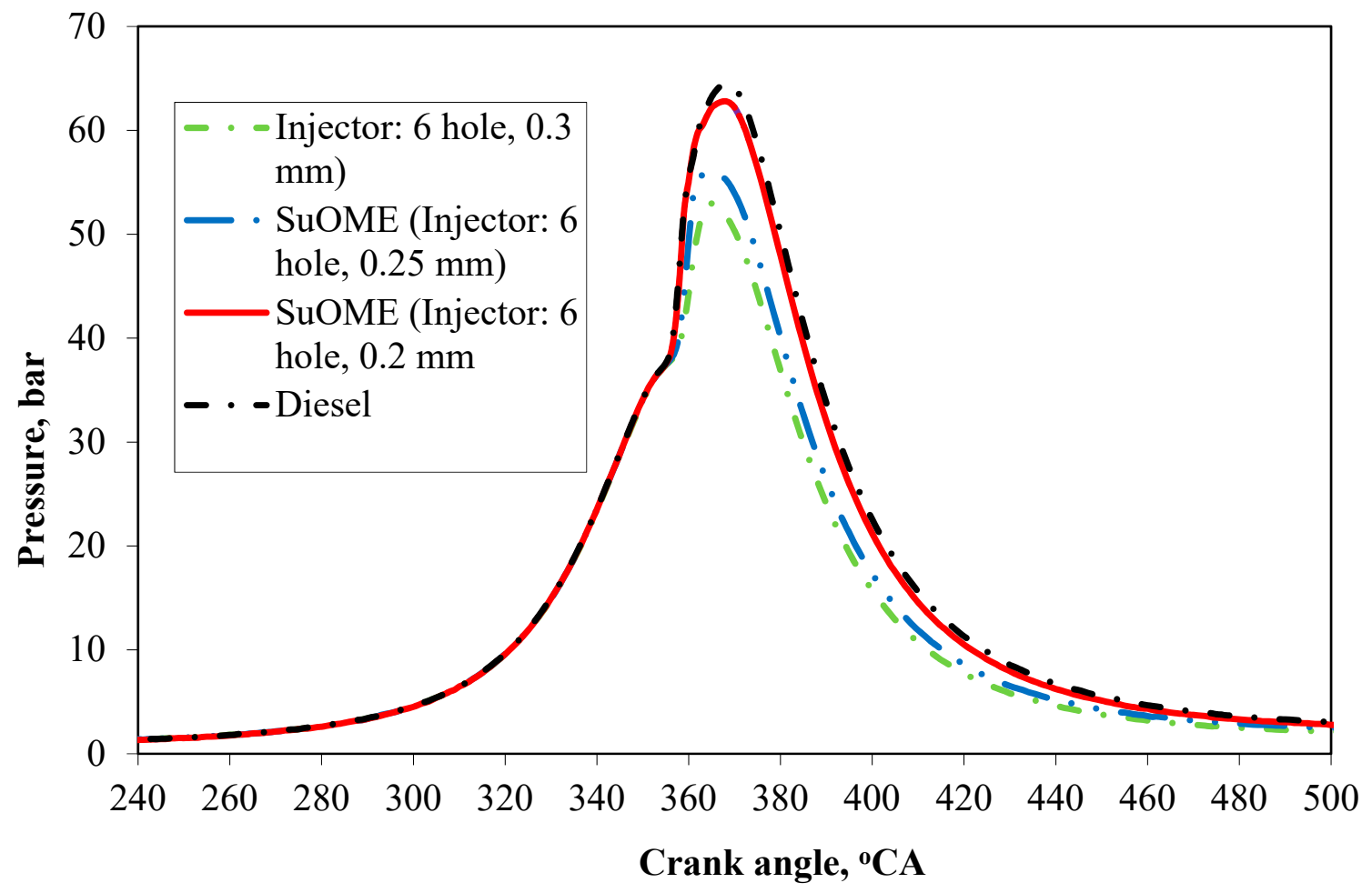

(a)

Figure 7. Cont. 


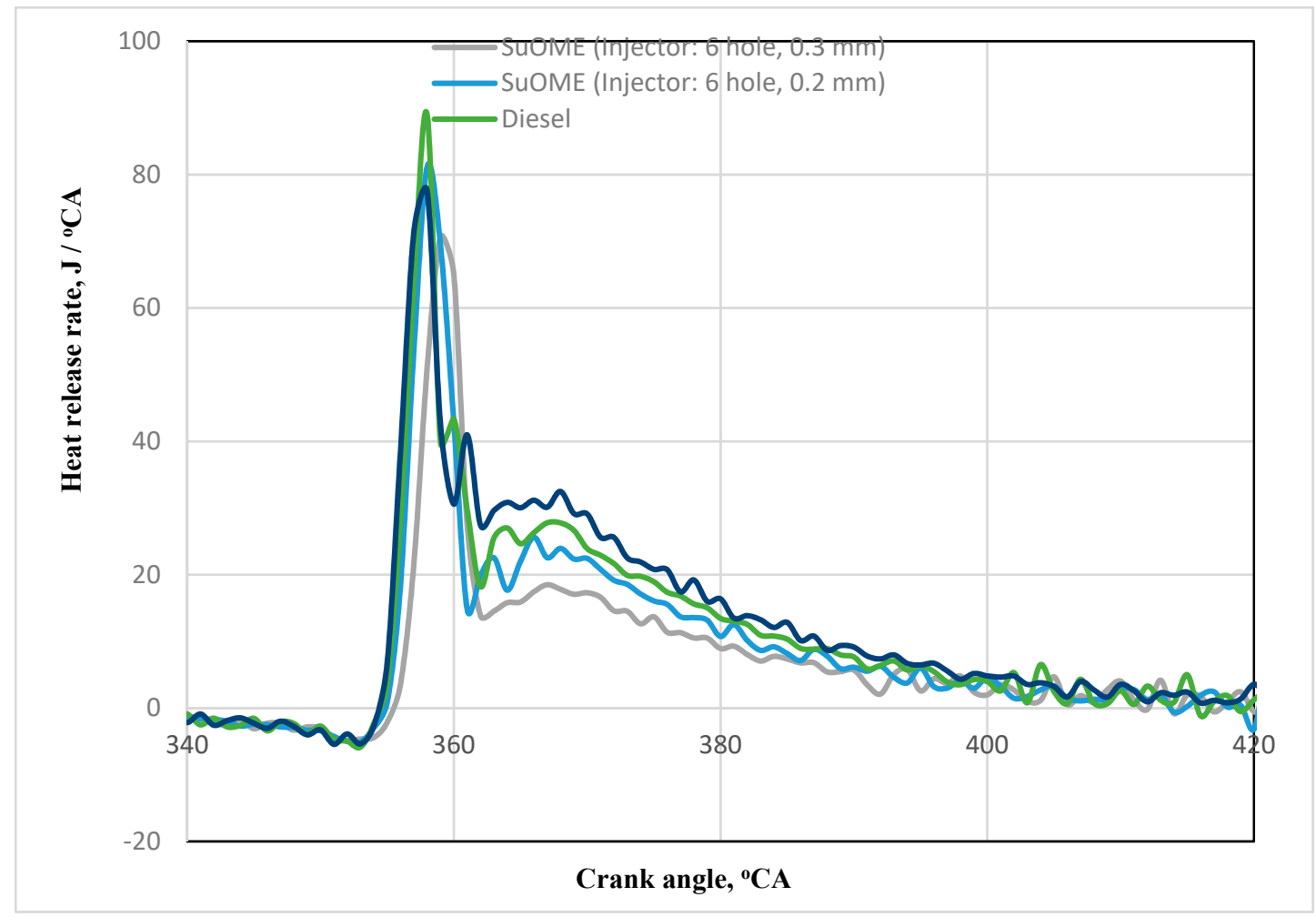

(b)

Figure 7. Variations of (a) in-cylinder pressure and (b) HRR with crank angle.

The variation of heat release rate with SuOME and diesel fuel for different injectors are shown in Figure $7 \mathrm{~b}$. A higher heat release rate was observed from diesel compared to SuOME. This may be attributed to diesel fuel burning in the premixed phase because of the higher volatility of SuOME. A higher performance for diesel was also observed mainly due to this reason. A higher peak was observed for SuOME than diesel under diffusion during the phase [65]. Hence combustion rates were higher during later stages of combustion with SuOME. Hence, it produced increased exhaust emissions and reduced brake thermal efficiency. Due to the later combustion, $\mathrm{NO}_{\mathrm{x}}$ emissions from SuOME were lower than emissions from diesel $[27,33,46]$.

\section{Conclusions}

A detailed experimental study on the viability of SuOME in the CI engine was carried out, and it was observed that the performance and combustion parameters were lesser than diesel. In the present study, an attempt was made to improve the performance of a SuOME operated engine by appropriately adjusting a few engine parameters such as fuel injection pressure and nozzle geometry. Injecting SuOME fuel into the cylinder up to 240 bar from 205 bar showed improved performance with reduced emissions. Further increasing the fuel injection pressure recorded unfavorable results. Further, to improve the SuOME operated engine's efficiency, a four, five, and six-hole injector was used and compared with a standard three-hole injector. Increasing the injector holes up to six holes improved the engine's performance with reduced emissions for SuOME mode.

Further study was also carried out on varying the injector orifice diameter. A further increase in engine combustion was observed by reducing the orifice diameter from 0.3 to $0.2 \mathrm{~mm}$. Finally, to conclude, operating the engine by slightly varying the manufacturer standards settings such as increasing fuel injection pressure and the number of injector holes and reducing the injector orifice diameter, a direct injection $\mathrm{CI}$ engine can be operated by SuOME fuel to obtain a considerably increased performance of the engine. In future 
studies, the emissions and losses (combustion, exhaust, heat transfer, and pumping), and energy balance should be evaluated to optimize the combustion from emissions, and efficiencies can be carried out. For 240 bar compared to 205 bar of injection pressure (IP) for SuOME, the BTE increased by $2.35 \%$, and smoke opacity reduced $1.45 \%$. For the six-hole fuel injector compared to a three-hole injector, the BTE increased by $3.19 \%$, HC reduced by $9.5 \%$, and CO reduced by $14.7 \%$. At 240 bar IP, for the six-hole injector with a $0.2 \mathrm{~mm}$ hole diameter compared to $0.3 \mathrm{~mm}$ hole diameter, the BTE increased by $5 \%$, HC reduced by $5.26 \%$, CO reduced by $25.61 \%$, and smoke reduced by $10 \%$, while $\mathrm{NO}_{\mathrm{x}}$ increased marginally by $0.27 \%$. Hence, the six-hole FI, $240 \mathrm{IP}$, and $0.2 \mathrm{~mm}$ FI diameter holes are suitable for diesel engine operation fueled by Simarouba biodiesel.

Author Contributions: K.K.N.: conceptualization, methodology, writing-Original Draft. T.K.C. and N.R.B.: Supervision, investigation, project administration and resources. J.G.S.: conceptualization, writing, review and editing. M.E.M.S.: interpretation of results, review and Editing, formal analysis. A.E.A.: Funding, review and editing. M.G.: Project administration, review and editing. A.E.: Support, review and editing. M.A.M., M.I.H.S. and M.A.A.: formal analyses, review and editing. All authors have read and agreed to the published version of the manuscript.

Funding: Deanship of Scientific Research at King Khalid University for the support through General Research Project under the grant number (R.G.P.2/138/42). Taif University researchers supporting project number (TURSP-2020/40), Taif University, Taif, Saudi Arabia.

Institutional Review Board Statement: Not applicable.

Informed Consent Statement: Not applicable.

Data Availability Statement: Not applicable.

Acknowledgments: The co-author Ali E. Anqi would like to extend his appreciation to the Deanship of Scientific Research at King Khalid University for the support he received through the General Research Project under the grant number (R.G.P.2/138/42). This work was also supported by Taif University researchers supporting project number (TURSP-2020/40), Taif University, Taif, Saudi Arabia.

Conflicts of Interest: The authors declare no conflict of interest.

\section{References}

1. Jena, P.C.; Raheman, H.; Kumar, G.P.; Machavaram, R. Biodiesel production from mixture of mahua and simarouba oils with high free fatty acids. Biomass Bioenergy 2010, 34, 1108-1116. [CrossRef]

2. Paramashivaiah, B.; Banapurmath, N.; Rajashekhar, C.; Khandal, S. Studies on effect of graphene nanoparticles addition in different levels with simarouba biodiesel and diesel blends on performance, combustion and emission characteristics of $\mathrm{CI}$ engine. Arab. J. Sci. Eng. 2018, 43, 4793-4801. [CrossRef]

3. Monsalve-Serrano, J.; Belgiorno, G.; Di Blasio, G.; Guzmán-Mendoza, M. 1D Simulation and Experimental Analysis on the Effects of the Injection Parameters in Methane-Diesel Dual-Fuel Combustion. Energies 2020, 13, 3734. [CrossRef]

4. Beatrice, C.; Belgiorno, G.; Di Blasio, G.; Mancaruso, E.; Sequino, L.; Vaglieco, B.M. Analysis of a Prototype High-Pressure "Hollow Cone Spray" Diesel Injector Performance in Optical and Metal Research Engines; SAE Technical Paper; SAE International: Warrendale, PA, USA, 2017.

5. Hossain, N.; Mahlia, T.M.I.; Miskat, M.I.; Chowdhury, T.; Barua, P.; Chowdhury, H.; Nizamuddin, S.; Ahmad, N.B.; Zaharin, N.A.B.; Mazari, S.A. Bioethanol production from forest residues and life cycle cost analysis of bioethanol-gasoline blend on transportation sector. J. Environ. Chem. Eng. 2021, 9, 105542. [CrossRef]

6. Soudagar, M.E.M.; Nik-Ghazali, N.-N.; Kalam, M.; Badruddin, I.A.; Banapurmath, N.; Khan, T.Y.; Bashir, M.N.; Akram, N.; Farade, R.; Afzal, A. The effects of graphene oxide nanoparticle additive stably dispersed in dairy scum oil biodiesel-diesel fuel blend on CI engine: Performance, emission and combustion characteristics. Fuel 2019, 257, 116015. [CrossRef]

7. Dimitrakopoulos, N.; Belgiorno, G.; Tunér, M.; Tunestål, P.; Di Blasio, G. Effect of EGR routing on efficiency and emissions of a PPC engine. Appl. Therm. Eng. 2019, 152, 742-750. [CrossRef]

8. El-Seesy, A.I.; Hassan, H.; Ibraheem, L.; He, Z.; Soudagar, M.E.M. Combustion, emission, and phase stability features of a diesel engine fueled by Jatropha/ethanol blends and n-butanol as co-solvent. Int. J. Green Energy 2020, 17, 793-804. [CrossRef]

9. Mujtaba, M.; Masjuki, H.; Kalam, M.; Ong, H.C.; Gul, M.; Farooq, M.; Soudagar, M.E.M.; Ahmed, W.; Harith, M.; Yusoff, M. Ultrasound-assisted process optimization and tribological characteristics of biodiesel from palm-sesame oil via response surface methodology and extreme learning machine-Cuckoo search. Renew. Energy 2020, 158, 202-214. [CrossRef] 
10. Sayin Kul, B.; Kahraman, A. Energy and Exergy Analyses of a Diesel Engine Fuelled with Biodiesel-Diesel Blends Containing 5\% Bioethanol. Entropy 2016, 18, 387. [CrossRef]

11. Delvi, M.K.; Soudagar, M.E.M.; Khan, H.; Ahmed, Z.; Shariff, I.M. Biodiesel production utilizing diverse sources, classification of oils and their esters, performance and emission characteristics: A research. Int. J. Recent Technol. Eng. 2019, 8, 976-983. [CrossRef]

12. Razzaq, L.; Farooq, M.; Mujtaba, M.; Sher, F.; Farhan, M.; Hassan, M.T.; Soudagar, M.E.M.; Atabani, A.; Kalam, M.; Imran, M. Modeling viscosity and density of ethanol-diesel-biodiesel ternary blends for sustainable environment. Sustainability 2020, 12, 5186. [CrossRef]

13. Gavhane, R.S.; Kate, A.M.; Pawar, A.; Safaei, M.R.; Soudagar, M.E.M.; Mujtaba Abbas, M.; Muhammad Ali, H.; Banapurmath, N.R.; Goodarzi, M.; Badruddin, I.A. Effect of Zinc Oxide Nano-Additives and Soybean Biodiesel at Varying Loads and Compression Ratios on VCR Diesel Engine Characteristics. Symmetry 2020, 12, 1042. [CrossRef]

14. Khan, H.; Soudagar, M.E.M.; Kumar, R.H.; Safaei, M.R.; Farooq, M.; Khidmatgar, A.; Banapurmath, N.R.; Farade, R.A.; Abbas, M.M.; Afzal, A. Effect of Nano-Graphene Oxide and n-Butanol Fuel Additives Blended with Diesel—Nigella sativa Biodiesel Fuel Emulsion on Diesel Engine Characteristics. Symmetry 2020, 12, 961. [CrossRef]

15. Soudagar, M.E.M.; Nik-Ghazali, N.-N.; Kalam, M.; Badruddin, I.A.; Banapurmath, N.; Ali, M.A.B.; Kamangar, S.; Cho, H.M.; Akram, N. An investigation on the influence of aluminium oxide nano-additive and honge oil methyl ester on engine performance, combustion and emission characteristics. Renew. Energy 2020, 146, 2291-2307. [CrossRef]

16. Hussain, F.; Soudagar, M.E.M.; Afzal, A.; Mujtaba, M.; Fattah, I.; Naik, B.; Mulla, M.H.; Badruddin, I.A.; Khan, T.; Raju, V.D. Enhancement in Combustion, Performance, and Emission Characteristics of a Diesel Engine Fueled with Ce-ZnO Nanoparticle Additive Added to Soybean Biodiesel Blends. Energies 2020, 13, 4578. [CrossRef]

17. Mujtaba, M.; Masjuki, H.; Kalam, M.; Noor, F.; Farooq, M.; Ong, H.C.; Gul, M.; Soudagar, M.E.M.; Bashir, S.; Rizwanul Fattah, I. Effect of Additivized Biodiesel Blends on Diesel Engine Performance, Emission, Tribological Characteristics, and Lubricant Tribology. Energies 2020, 13, 3375. [CrossRef]

18. Mujtaba, M.A.; Kalam, M.A.; Masjuki, H.H.; Razzaq, L.; Khan, H.M.; Soudagar, M.E.M.; Gul, M.; Ahmed, W.; Raju, V.D.; Kumar, R.; et al. Development of empirical correlations for density and viscosity estimation of ternary biodiesel blends. Renew. Energy 2021, 179, 1447-1457. [CrossRef]

19. Fayaz, H.; Mujtaba, M.; Soudagar, M.E.M.; Razzaq, L.; Nawaz, S.; Nawaz, M.A.; Farooq, M.; Afzal, A.; Ahmed, W.; Khan, T.Y. Collective effect of ternary nano fuel blends on the diesel engine performance and emissions characteristics. Fuel 2021, 293, 120420. [CrossRef]

20. Soudagar, M.E.M.; Nik-Ghazali, N.-N.; Kalam, M.A.; Badruddin, I.; Banapurmath, N.; Akram, N. The effect of nano-additives in diesel-biodiesel fuel blends: A comprehensive review on stability, engine performance and emission characteristics. Energy Convers. Manag. 2018, 178, 146-177. [CrossRef]

21. Mujtaba, M.; Kalam, M.; Masjuki, H.; Gul, M.; Soudagar, M.E.M.; Ong, H.C.; Ahmed, W.; Atabani, A.; Razzaq, L.; Yusoff, M. Comparative study of nanoparticles and alcoholic fuel additives-biodiesel-diesel blend for performance and emission improvements. Fuel 2020, 279, 118434. [CrossRef]

22. Khan, H.M.; Iqbal, T.; Yasin, S.; Irfan, M.; Kazmi, M.; Fayaz, H.; Mujtaba, M.; Ali, C.H.; Kalam, M.; Soudagar, M.E.M. Production and utilization aspects of waste cooking oil based biodiesel in Pakistan. Alex. Eng. J. 2021, 60, 5831-5849. [CrossRef]

23. Bala Prasad, K.; Dhana Raju, V.; Ahamad Shaik, A.; Gopidesi, R.K.; Sreekara Reddy, M.B.S.; Soudagar, M.E.M.; Mujtaba, M.A. Impact of injection timings and exhaust gas recirculation rates on the characteristics of diesel engine operated with neat tamarind biodiesel. Energy Sources Part A Recovery Util. Environ. Eff. 2021, 1-19. [CrossRef]

24. Kareemullah, M.; Afzal, A.; Rehman, K.F.; KC, V.; Khan, H.; Soudagar, M.E.M.; Kaladgi, A.R. Preparation and physicochemical properties evaluation of epoxidized neem oil-based bio-lubricant. Aust. J. Mech. Eng. 2021, 1-10. [CrossRef]

25. Fattah, I.R.; Masjuki, H.; Kalam, M.; Wakil, M.; Rashedul, H.; Abedin, M. Performance and emission characteristics of a CI engine fueled with Cocos nucifera and Jatropha curcas B20 blends accompanying antioxidants. Ind. Crop. Prod. 2014, 57, 132-140. [CrossRef]

26. Balaji, G.; Cheralathan, M. Experimental investigation of varying the fuel injection pressure in a direct injection diesel engine fuelled with methyl ester of neem oil. Int. J. Ambient. Energy 2017, 38, 356-364. [CrossRef]

27. Khandal, S.; Banapurmath, N.; Gaitonde, V.; Hosmath, R. Effect of number of injector nozzle holes on the performance, emission and combustion characteristics of Honge oil biodiesel (HOME) operated DI compression ignition engine. J. Pet. Environ. Biotechnol. 2015, 6, 2.

28. Palani, R.; Nallusamy, N.; Pitchandi, K. Spray characteristics of diesel and derivatives in direct injection diesel engines with varying injection pressures. J. Mech. Sci. Technol. 2015, 29, 4465-4471. [CrossRef]

29. Mohan, B.; Yang, W.; Raman, V.; Sivasankaralingam, V.; Chou, S.K. Optimization of biodiesel fueled engine to meet emission standards through varying nozzle opening pressure and static injection timing. Appl. Energy 2014, 130, 450-457. [CrossRef]

30. Wetzel, J. Optical analysis of the influence of injector hole geometry on mixture formation in gasoline direct injection engines. Automot. Engine Technol. 2016, 1, 57-67. [CrossRef]

31. Imoehl, W.; Gestri, L.; Maragliulo, M.; Del-Frate, L.; Klepatsch, M.; Wildeson, R. A DOE approach to engine deposit testing used to optimize the design of a gasoline direct injector seat and orifice. SAE Int. J. Fuels Lubr. 2012, 5, 1078-1095. [CrossRef]

32. Postrioti, L.; Cavicchi, A.; Brizi, G.; Berni, F.; Fontanesi, S. Experimental and Numerical Analysis of Spray Evolution, Hydraulics and Atomization for a 60 MPa Injection Pressure GDI System; SAE Technical Paper; SAE International: Warrendale, PA, USA, 2018. 
33. Verma, A.; Rawat, K.; Saify, M.; Singh, A.; Maheshwari, P. Performance Analysis of CI Engine Powered with Simarouba Glauca L. Biodiesel Fuel. In Advances in Materials Engineering and Manufacturing Processes; Springer: Berlin/Heidelberg, Germany, 2020; pp. 41-50.

34. Mishra, S.; Mohanty, M.; Panigrahi, N.; Pattanaik, A. Impact of Simarouba glauca biodiesel blends as a fuel on the performance and emission analysis in an unmodified DICI engine. Renew. Energy Focus 2018, 26, 11-16. [CrossRef]

35. Mishra, S.; Mohanty, M.; Das, S.; Pattanaik, A. Production of bio-diesel (Methyl Ester) from Simarouba glauca oil. Res. J. Chem. Sci. 2012, 2231, 606X.

36. Jeyalakshmi, P. Characterization of Simarouba glauca seed oil biodiesel. J. Therm. Anal. Calorim. 2019, 136, 267-280. [CrossRef]

37. Bala Prasad, K.; Meduri, O.; Dhana Raju, V.; Azmeera, A.K.; Venu, H.; Subramani, L.; Soudagar, M.E.M. Effect of split fuel injection strategies on the diverse characteristics of CRDI diesel engine operated with tamarind biodiesel. Energy Sources Part A Recovery Util. Environ. Eff. 2020, 1-19. [CrossRef]

38. Venu, H.; Raju, V.D.; Lingesan, S.; Soudagar, M.E.M. Influence of $\mathrm{Al}_{2} \mathrm{O}_{3}$ nano additives in ternary fuel (diesel-biodiesel-ethanol) blends operated in a single cylinder diesel engine: Performance, Combustion and Emission Characteristics. Energy 2021, 215, 119091. [CrossRef]

39. Wang, S.; Karthickeyan, V.; Sivakumar, E.; Lakshmikandan, M. Experimental investigation on pumpkin seed oil methyl ester blend in diesel engine with various injection pressure, injection timing and compression ratio. Fuel 2020, 264, 116868. [CrossRef]

40. Deep, A.; Sandhu, S.S.; Chander, S. Experimental investigations on the influence of fuel injection timing and pressure on single cylinder CI engine fueled with $20 \%$ blend of castor biodiesel in diesel. Fuel 2017, 210, 15-22. [CrossRef]

41. Shrivastava, P.; Verma, T.N. Effect of fuel injection pressure on the characteristics of CI engine fuelled with biodiesel from Roselle oil. Fuel 2020, 265, 117005. [CrossRef]

42. Yesilyurt, M.K. The effects of the fuel injection pressure on the performance and emission characteristics of a diesel engine fuelled with waste cooking oil biodiesel-diesel blends. Renew. Energy 2019, 132, 649-666. [CrossRef]

43. Tumbal, A.; Banapurmath, N.; Tewari, P. Effect of injection timing, injector opening pressure, injector nozzle geometry, and swirl on the performance of a direct injection, compression-ignition engine fuelled with honge oil methyl ester (HOME). Int. J. Automot. Technol. 2016, 17, 35-50. [CrossRef]

44. Keerthi Kumar, N.; Jatadhara, G.S.; Chandrashekar, T.K. Experimental Study on Characteristics of Direct Injection Compressed Ignition Engine Using Waste Plastic Oil and Biodiesel Blends. Int. J. Mech. Prod. Eng. Res. Dev. 2020, 10, $2085-2094$.

45. Kumar, N.K.; Chandrashekar, T.; Banapurmath, N. Effects of combustion chamber profile on direct injection diesel engine operated with SuOME. AIP Conf. Proc. 2019, 2128, 050001.

46. Soudagar, M.E.M.; Mujtaba, M.; Safaei, M.R.; Afzal, A.; Ahmed, W.; Banapurmath, N.; Hossain, N.; Bashir, S.; Badruddin, I.A.; Goodarzi, M. Effect of Sr@ ZnO nanoparticles and Ricinus communis biodiesel-diesel fuel blends on modified CRDI diesel engine characteristics. Energy 2021, 215, 119094. [CrossRef]

47. Mujtaba, M.; Cho, H.M.; Masjuki, H.; Kalam, M.; Farooq, M.; Soudagar, M.E.M.; Gul, M.; Afzal, A.; Ahmed, W.; Raza, A. Effect of primary and secondary alcohols as oxygenated additives on the performance and emission characteristics of diesel engine. Energy Rep. 2021, 7, 1116-1124. [CrossRef]

48. Mujtaba, M.; Cho, H.M.; Masjuki, H.; Kalam, M.; Farooq, M.; Soudagar, M.E.M.; Gul, M.; Ahmed, W.; Afzal, A.; Bashir, S. Effect of alcoholic and nano-particles additives on tribological properties of diesel-palm-sesame-biodiesel blends. Energy Rep. 2021, 7, 1162-1171. [CrossRef]

49. Mujtaba, M.; Kalam, M.; Masjuki, H.; Soudagar, M.E.M.; Khan, H.M.; Fayaz, H.; Farooq, M.; Gul, M.; Ahmed, W.; Ahmad, M. Effect of palm-sesame biodiesel fuels with alcoholic and nanoparticle additives on tribological characteristics of lubricating oil by four ball tribo-tester. Alex. Eng. J. 2021, 60, 4537-4546. [CrossRef]

50. Sayin, C.; Gumus, M.; Canakci, M. Influence of injector hole number on the performance and emissions of a DI diesel engine fueled with biodiesel-diesel fuel blends. Appl. Therm. Eng. 2013, 61, 121-128. [CrossRef]

51. Raju, V.D.; Reddy, S.R.; Venu, H.; Subramani, L.; Soudagar, M.E.M. Effect of Nanoparticles in Bio-Oil on the Performance, Combustion and Emission Characteristics of a Diesel Engine. Liq. Biofuels Fundam. Charact. Appl. 2021, 613-637. [CrossRef]

52. Banapurmath, N.R.; Soudagar, M.E.; Ganachari, S.V.; Kulkarni, P.S.; Kumar, N.K.; Yaliwal, V. An exhaustive study on the use of Jatropha based biodiesel for modern diesel engine applications. In Biodiesel Fuels Based on Edible and Nonedible Feedstocks, Wastes, and Algae; CRC Press: Boca Raton, FL, USA, 2021; pp. 541-559.

53. Soudagar, M.E.M.; Khan, H.M.; Khan, T.; Razzaq, L.; Asif, T.; Mujtaba, M.; Hussain, A.; Farooq, M.; Ahmed, W.; Shahapurkar, K. Experimental Analysis of Engine Performance and Exhaust Pollutant on a Single-Cylinder Diesel Engine Operated Using Moringa Oleifera Biodiesel. Appl. Sci. 2021, 11, 7071. [CrossRef]

54. Khan, H.; Kareemullah, M.; Ravi, H.; Rehman, K.F.; Kumar, R.H.; Afzal, A.; Soudagar, M.E.M.; Fayaz, H. Combined effect of synthesized waste milk scum oil methyl ester and ethanol fuel blend on the diesel engine characteristics. J. Inst. Eng. Ser. C 2020, 101, 947-962. [CrossRef]

55. Harari, P.A.; Banapurmath, N.R.; Yaliwal, V.S.; Soudagar, M.E.M.; Khan, T.M.Y.; Mujtaba, M.A.; Safaei, M.R.; Akram, N.; Goodarzi, M.; Elfasakhany, A.; et al. Experimental investigation on compression ignition engine powered with pentanol and thevetia peruviana methyl ester under reactivity controlled compression ignition mode of operation. Case Stud. Therm. Eng. 2021, 25, 100921. [CrossRef] 
56. Akkoli, K.M.; Banapurmath, N.R.; Shivashimpi, M.M.; Soudagar, M.E.M.; Badruddin, I.A.; Alazwari, M.A.; Yaliwal, V.S.; Mujtaba, M.A.; Akram, N.; Goodarzi, M.; et al. Effect of injection parameters and producer gas derived from redgram stalk on the performance and emission characteristics of a diesel engine. Alex. Eng. J. 2021, 60, 3133-3142. [CrossRef]

57. Lahane, S.; Subramanian, K. Impact of nozzle holes configuration on fuel spray, wall impingement and $\mathrm{NO}_{\mathrm{x}}$ emission of a diesel engine for biodiesel-diesel blend (B20). Appl. Therm. Eng. 2014, 64, 307-314. [CrossRef]

58. Kim, T.; Park, J.; Cho, H. Emission Characteristics under Diesel and Biodiesel Fueled Compression Ignition Engine with Various Injector Holes and EGR Conditions. Energies 2020, 13, 2973. [CrossRef]

59. Soudagar, M.E.M.; Banapurmath, N.; Afzal, A.; Hossain, N.; Abbas, M.M.; Haniffa, M.A.C.M.; Naik, B.; Ahmed, W.; Nizamuddin, S.; Mubarak, N. Study of diesel engine characteristics by adding nanosized zinc oxide and diethyl ether additives in Mahua biodiesel-diesel fuel blend. Sci. Rep. 2020, 10, 15326. [CrossRef] [PubMed]

60. Suh, H.; Park, S.; Lee, C. Effect of grouped-hole nozzle geometry on the improvement of biodiesel fuel atomization characteristics in a compression ignition engine. Proc. Inst. Mech. Eng. Part D J. Automob. Eng. 2009, 223, 1587-1600. [CrossRef]

61. Wategave, S.; Banapurmath, N.; Sawant, M.; Soudagar, M.E.M.; Mujtaba, M.; Afzal, A.; Basha, J.S.; Alazwari, M.A.; Safaei, M.R.; Elfasakhany, A. Clean combustion and emissions strategy using reactivity controlled compression ignition (RCCI) mode engine powered with CNG-Karanja biodiesel. J. Taiwan Inst. Chem. Eng. 2021, 124, 116-131. [CrossRef]

62. Kumar, M.V.; Babu, A.V.; Kumar, P.R. Experimental investigation on the effects of diesel and mahua biodiesel blended fuel in direct injection diesel engine modified by nozzle orifice diameters. Renew. Energy 2018, 119, 388-399. [CrossRef]

63. Indudhar, M.; Banapurmath, N.; Rajulu, K.G.; Khan, T.Y.; Manoj, E. Effects of single and split injection on the performance, emission and combustion attributes of a CRDI engine powered with diesel and honge biodiesel. Sustain. Energy Fuels 2019, 3, 2275-2286. [CrossRef]

64. Kattimani, S.S.; Topannavar, S.; Shivashimpi, M.; Dodamani, B. Experimental investigation to optimize fuel injection strategies and compression ratio on single cylinder DI diesel engine operated with FOME biodiesel. Energy 2020, 200, 117336. [CrossRef]

65. Razzaq, L.; Imran, S.; Anwar, Z.; Farooq, M.; Abbas, M.M.; Mehmood Khan, H.; Asif, T.; Amjad, M.; Soudagar, M.E.M.; Shaukat, N. Maximising yield and engine efficiency using optimised waste cooking oil biodiesel. Energies 2020, 13, 5941. [CrossRef] 